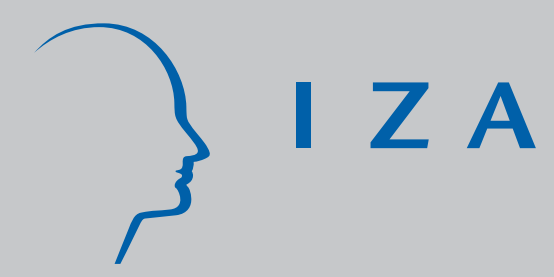

IZA DP No. 1726

The Linguistic and Economic Adjustment of Soviet Jewish Immigrants in the United States, 1980 to 2000

Barry R. Chiswick

Michael Wenz

August 2005 


\title{
The Linguistic and Economic Adjustment of Soviet Jewish Immigrants in the United States, 1980 to 2000
}

\author{
Barry R. Chiswick \\ University of Illinois at Chicago \\ and IZA Bonn \\ Michael Wenz \\ University of Illinois at Chicago
}

\section{Discussion Paper No. 1726 \\ August 2005}

IZA

P.O. Box 7240

53072 Bonn

Germany

Phone: +49-228-3894-0
Fax: +49-228-3894-180
Email: iza@iza.org

Any opinions expressed here are those of the author(s) and not those of the institute. Research disseminated by IZA may include views on policy, but the institute itself takes no institutional policy positions.

The Institute for the Study of Labor (IZA) in Bonn is a local and virtual international research center and a place of communication between science, politics and business. IZA is an independent nonprofit company supported by Deutsche Post World Net. The center is associated with the University of Bonn and offers a stimulating research environment through its research networks, research support, and visitors and doctoral programs. IZA engages in (i) original and internationally competitive research in all fields of labor economics, (ii) development of policy concepts, and (iii) dissemination of research results and concepts to the interested public.

IZA Discussion Papers often represent preliminary work and are circulated to encourage discussion. Citation of such a paper should account for its provisional character. A revised version may be available directly from the author. 


\section{ABSTRACT}

\section{The Linguistic and Economic Adjustment of Soviet Jewish Immigrants in the United States, 1980 to $2000^{*}$}

This paper is an analysis of the English-language proficiency and labor market earnings of adult male Soviet Jewish immigrants to the United States from 1965 to 2000, using the 2000 Census of Population. Comparisons are made to similar analyses using the 1980 and 1990 Censuses. A consistent finding is that recently arrived Soviet Jewish immigrants have lower levels of English proficiency and earnings than other immigrants, other variables being the same. However, they have a steeper improvement in both proficiency and earnings with duration in the United States and the differences from the other European immigrants disappear after a few years. The Soviet Jewish immigrants have both a higher level of schooling and a larger effect of schooling on earnings than other immigrants, even other European immigrants. The lower initial English proficiency and earnings, the steeper improvement with duration and the rapid attainment of parity is consistent with the "refugee" nature of their migration, as distinct from being purely economic migrants. That the same pattern exists across three censuses suggests that the low English proficiency and earnings of those recently arrived in the 2000 Census data reflects a refugee assimilation process, and not a decline in the unmeasured dimensions of the earnings potential of recent cohorts of Soviet Jewish immigrants. The very high level of schooling and the larger effect of schooling on earnings among Soviet Jewish immigrants is similar to the patterns found among Jews born in the United States. Soviet Jewish immigrants appear to have made a very successful linguistic and labor market adjustment, regardless of their period of entry into the United States.

JEL Classification: $\quad$ F22, J6, J31, J24

Keywords: earnings, language proficiency, immigrants, Jews, Soviet Union

Corresponding author:

Barry R. Chiswick

Department of Economics (M/C 144)

University of Illinois at Chicago

601 South Morgan Street (2103 UH)

Chicago, IL 60607-7121

USA

Email: brchis@uic.edu

\footnotetext{
* Earlier versions of this paper were presented at the Conference on Soviet and Post-Soviet Jewry, Hebrew University, Jerusalem, December, 28-30, 2003, the Conference on Immigration, Minorities and Social Exclusion, Bar-Ilan University, June 27-28, 2004, and the Fourteenth World Congress of Jewish Studies, Jerusalem, August 2005. Chiswick acknowledges the research support of the Institute of Government and Public Affairs, University of Illinois. Comments on earlier version from Carmel U. Chiswick, Allen Glicksman, and Mark Tolts are appreciated.
} 


\section{“The Linguistic and Economic Adjustment of Soviet Jewish Immigrants in the United States, 1980 to 2000”}

\section{Introduction}

This study constitutes an extension of earlier work by one of the authors on the economic status of turn-of-the- $20^{\text {th }}$ century Russian Jewish immigrants, as well as work on Soviet Jewish immigrants to the United States in the late $20^{\text {th }}$ century (Chiswick, 1991, 1992, 1993, 1997, 1999). The specific purpose of this paper is to continue this line of research on the linguistic and labor market adaptation of adult male Soviet Jewish immigrants in the United States in the post1965 period. $^{1}$ Linguistic adaptation, that is, the acquisition of English language proficiency, is important for many reasons, including increasing access to U.S. schooling and job training and success in the labor market, whether measured by employment or earnings. Moreover, it is important for acquiring U.S. citizenship and thereby expanding job opportunities and increasing political influence. Labor market success is an important element in a family's economic wellbeing and determines current consumption, as well as having an influence on marital formation and stability, fertility, and parental investments in the human capital of their children.

1 Analyses using a similar methodology have been conducted for the Hebrew language proficiency and labor market earnings of Jewish immigrants in Israel. See Chiswick (1988) and Chiswick and Repetto (2001) for analyses of the 1972 and 1983 Censuses of Israel. Unfortunately, the 1995 Census did not include any questions on language usage or language proficiency. The U.S. and Israel studies are not strictly comparable because of differences in the Census questionnaires, the nature of immigration into these two countries, the relative magnitudes of the immigration flows after the collapse of the Soviet Union (small for the U.S., large for Israel) and the differences in the local (native) populations. Israel policy regarding intensive efforts to promote Hebrew language usage among immigrants was relaxed with regards to the Russian-speaking immigrants who arrived following the collapse of the former Soviet Union. For a discussion of this implicit change in policy see Glinert (1995). 
The data under study are from the 2000 Census of Population of the United States, Public Use Microdata Sample (Census, 2003), 5 percent random sample of the population, as well as comparable data from the 1980 and 1990 Censuses. $^{2}$

\section{Migration from the Former Soviet Union}

\section{(a) The Extent of Migration}

With the impending and actual collapse of the Soviet Union in 1989 a massive exodus began of the Jewish population. Between 1989 and 2003, 1.6 million Jews and their non-Jewish relatives left the former Soviet Union (FSU), 200,000 each in 1990 and 1991 alone, with the numbers declining thereafter to only 35,000 in 2003 (Tolts, 2004a 2004b). The primary destination was, of course, Israel which received over 950,000, or 61 percent of the emigrants. The emigration data suggest that about 315,000 Jews and their non-Jewish relatives left the FSU for the United States, or about 20 percent of the emigrants. Another 160,000 (10 percent) went to Germany and about 20,000 went to Canada, with the remainder settling in a wide range of destinations. $^{3}$

From the start of official record keeping in the United States in 1820, to the present, approximately 4.0 million people are recorded as having immigrated (permanent resident aliens) to the United States from the Russian Empire or the former Soviet Union (Table 1). The peak

2 In principle, data from the recently released National Jewish Population Survey (NJPS) 2000/01 can be used to study the economic status of Soviet Jewish immigrants. The NJPS 2000/01, however, provides a relatively smaller sample of Soviet Jews. Of the 5,148 respondents, both male and female age 18 and over, only 281 were born in the former Soviet Union.

${ }^{3}$ With the demise of the Soviet Union and the reunification with East Germany, Germany instituted a special immigration program to attract Soviet Jews to rebuild the German Jewish community (see Tress 1995). In 2005 the German government was taking steps to effectively close this program (Bernstein, 2005). 
decade was 1901-1910 when 1.6 million immigrants were recorded, followed by 1911-1920 with 0.9 million immigrants (Table 2). Immigration from the Soviet Union declined sharply thereafter, with less than 600 recorded in the 1940's, rising to nearly 700 in the 1950 's, 2,500 in the 1960 's, 39,000 in the 1970 's, 58,000 in the 1980's, and nearly 463,000 in the 1990's (19912000), for a total of 560,000 over the period 1965-2000. Because of these trends, the analysis is limited to those who first came to the United States to stay in 1965 or later.

The 2000 Census suggests that there were about 700,000 people living in the United States who were born in the former Soviet Union. They may have entered with permanent resident alien visas or under other visas and provisions of immigration law, and some of these subsequently became permanent resident aliens. A large proportion entered as refugees or asylees (Table 2).

\section{(b) The Refugee Experience}

Many who sought to leave the Soviet Union would not have had an incentive to leave if not for the anti-semitism and generalized repression. Many were motivated, at least in part, by these factors and not simply conventional economic incentives. There had been a pent up demand for emigration from the Soviet Union, but there had been little expectation that it could be realized. Most emigrants had a limited ability to prepare for the move because of the seemingly arbitrary nature of the Soviet bureaucracy and the apparent randomness as to whose application for an exit visa would be approved, or when it would be approved. Many who sought to leave before the collapse of the Soviet Union experienced various degrees of reprisals and persecution, including loss of their jobs and imprisonment or internal exile. The unexpected and sudden opening for emigration with the collapse of the Soviet Union was accompanied by fears that the door could close at any time accompanied by a resurgence of anti-semitism and 
repression. Thus, the Soviet Jewish migrants to the United States are more appropriately characterized as refugees than as economic migrants.

Refugees have a different adjustment in the destination than do economic migrants (Chiswick 1978, 1979). They have more skills specific to the origin and fewer skills that are destination specific or internationally transferable. As a result, at arrival they would be expected to have lower levels of human capital specific to the destination, including language skills, and hence lower earnings than economic migrants with similar measured characteristics. As they make implicit and explicit investments in the destination to increase the transferability of previously acquired skills and to create new skills, it would be expected that they would exhibit a more rapid improvement in language skills and earnings than economic migrants. Yet, because refugees are likely to be less favorably selected for economic success in the destination than otherwise similar economic migrants, it would be expected that the gap between them and economic migrants would narrow, but never close (Chiswick, 2000).

Moreover, because of the lesser degree of the transferability of the skills acquired in the origin in school and on the job (labor market experience) among refugees, the effects of these variables on their earnings in the U.S. would differ from that of economic mirants. In particular, refugees would be expected to have a smaller effect of schooling and pre-migration experience on earnings than would be the case for economic migrants.

While Soviet Jewish immigrants would reflect these refugee characteristics, these might be offset by the different labor market characteristics that have been exhibited by Jews in the U.S., whether immigrants or native born. American Jews have had high rates of occupation and earnings mobility, have a larger effect of schooling on earnings, and have obtained higher earnings, compared to observationally similar non-Jews (Chiswick 1999). 
As a result the linguistic and labor market progress of Soviet Jewish immigrants in the United States, in comparison to other (non-Jewish) economic migrants would be expected to reflect both their refugee and Jewish experiences and backgrounds.

\section{Who is a Soviet Jew?}

The first step in an analysis of "Soviet Jews" in the United States is to define each of the two terms. For the purpose of this study, persons born in any of the constituent republics of the Former Soviet Union are referred to as "Soviet immigrants". Thus, the analysis is not to be limited to those born in "Russia" loosely defined or in the Russian Federation.

Defining Jews is more problematic. The Census of the United States, unlike censuses in some other countries, such as Australia, Canada and Israel, has never asked religion. In the 2000 Census microdata file anyone who responds to the question on ethnic ancestry by revealing a religion is assigned the same ancestry code (998) as all other religious responses. Any response indicating Jewishness, even if the response is "secular Jew", is combined with and thereby masked with other religious responses.

Yet, clearly, not all respondents from the former Soviet Union are Jews. Those who report an Armenian ancestry or who report that they speak Armenian or Ukrainian at home are not likely to be Jewish. Thus, for a first approximation for the purposes of this paper, persons born in the former Soviet Union who do not report an Armenian ancestry, or Armenian or 
Ukrainian as a language spoken at home are the subject of this analysis and for simplicity of exposition are considered "Soviet Jews". 4 (Chiswick 1993, 1997).

This study is limited to the analysis of adult (age 25 to 64) males. For younger and older persons school enrollment and retirement decisions have a major impact on labor supply and choice of jobs, and hence earnings. Similarly, the labor market attachment of women is strongly influenced by marital status and child care responsibilities. Analyses of these labor supply decisions are beyond the scope of this study.

\section{Descriptive Statistics}

Table 3 reports the means and standard deviations of selected variables relevant for the analysis. The Soviet Jewish immigrants, as defined here, are less proficient in English than either European or Asian immigrants. Among the Soviet Jews 73 percent reported that they speak only English at home or speak another language but speak English "very well” or "well” (Tables 3 and 4). Twenty-seven percent reported that they spoke English "not well” or "not at all”. In contrast, 89 percent of the European immigrants and 82 percent of the Asian immigrants satisfy this definition of English proficiency. Among those with earnings, the Soviet Jews earned nearly $\$ 37,600$ in 1999 , considerably less than the earnings of other European $(\$ 50,900)$ and Asian $(\$ 42,400)$ immigrants, but substantially more than Latin American immigrants $(\$ 23,000)$.

\footnotetext{
${ }^{4}$ According to the 2000 Census, the ethnic origins (ancestry) of the adult (age 25 to 64) males born in the Soviet Union who immigrated in 1965 or later were 41 percent Russian, 20 percent Ukrainian, 11 percent Armenian, 10 percent response indicating a religion, 6 percent no ancestry reported and 13 percent other responses. By languages spoken in the home, “only English” was reported by 4 percent, Russian 72 percent, Armenian 9 percent, Ukrainian 7 percent, Yiddish 0.2 percent, and all other languages 8 percent. There was little variation in the reported ancestry or language by sub-period of immigration. See Appendix Tables A1-A2.
} 
The Soviet Jewish immigrants have some characteristics that would enhance their language proficiency and earnings potential, but other characteristics that would have a negative impact. Their educational level is very high, an average of 14.8 years of schooling, far greater than even the 14.1 years among Asian immigrants, the 13.6 years among other European immigrants, or the 11.5 years among all (including Soviet) immigrants. On the other hand, the Soviet immigrants had a very short period of residence in the U.S. In 2000, among those who immigrated in 1965 or later, 70 percent of the Soviet Jews had been in the U.S. 10 or fewer years, in contrast to 37 percent overall.

The two measures of employment tell a similar story. Among those who worked, the weeks worked in 1999 were lower for Soviet Jews (46.5 weeks) than for European (47.6 weeks) or Asian (46.8 weeks) immigrants, although greater than among Latin American immigrants (45.3 weeks). Among those in the labor force in the reference week, the last week in March 2000, 4.3 percent of the Soviet Jewish immigrants were unemployed, in contrast to 2.8 percent and 3.1 percent for European and Asian immigrants, respectively.

Table 4 provides greater detail on the English language proficiency of immigrants. The Soviet Jews are least likely to speak only English at home (4.5 percent compared to 13.4 percent for all immigrants) and are more likely (26.8 percent) than European and Asian immigrants to report that they speak English "not well” or "not at all (11.2 and 17.9 percent, respectively). Only the Latin American immigrants have a greater proportion (42.7 percent) in these two least proficient categories.

Appendix Tables A-1 to A-3 report the ethnic ancestry, language spoken at home if it is not exclusively English and the republic of birth for the sample of Soviet Jews under study by 
sub-period of immigration to the U.S. since 1965. There appears to be relatively little variation in these characteristics across the sub-periods. ${ }^{5}$

\section{Methodology for the Statistical Analysis}

A multivariate statistical analysis (ordinary least squares regression analysis, OLS) is used to compare Soviet Jewish immigrants to other immigrants, when other measured variables are held constant. That is, controlling for factors such as age, schooling, marital status, and duration in the United States, do Soviet Jews differ in English language proficiency and earnings from other immigrants? ${ }^{6}$

The statistical analysis uses the adult (age 25 to 64) male respondents in the 2000 Census Public Use Microdata Sample, five percent sample of the population, as the unit of observation. The means and standard deviations for the dependent and explanatory variables are reported in Table 3.

Language skills are measured by a dichotomous variable defined to equal unity for those who speak only English at home or if they speak another language they speak English "very well” or "well”. It is zero for those who speak English “not well” or "not at all” (See Table 4).

The earnings variable is the natural logarithm of annual earnings in 1999, where earnings are the sum of wage, salary and self-employment income. Those who reported zero earnings or did not work in 1999 are deleted from the analysis. Those who reported earnings of less than

\footnotetext{
5 The very low proportion reporting Yiddish reflects the very rapid decline in the use of Yiddish by Russian/Soviet Jews during the $20^{\text {th }}$ century. By the 1970's “for the great majority of contemporary Soviet Jews (80 percent of our respondents), Russian is the native language”, with the proportion being greater for younger Jews. Yiddish was spoken primarily by older Jews or when younger Jews were speaking with their parents (Karklins, 1987, p.29).

6 The schooling data cannot be decomposed into pre- and post-migration schooling, although given the age at migration there is likely to be little post-migration schooling among Soviet Jews.
} 
$\$ 100$, including the negligible number reporting negative earnings, were assigned a value of $\$ 100$ since the natural logarithm is not defined for zero or negative values. ${ }^{7}$

The econometric model for the analysis of language proficiency is based on earlier research that specifies three fundamental concepts (Chiswick and Miller 1998). These are exposure to the destination language, efficiency in destination language acquisition, and economic incentives for learning the destination language. In the empirical application the measurable variables reflecting these concepts include two continuous variables, years of schooling and years of age, and a set of dichotomous variables. The dichotomous variables include marital status (whether married, with spouse present), whether there are children under age 18 currently living in the household, and whether the respondent lives in a rural area or a southern state (the swath of 17 states from Texas to the Atlantic Ocean, from Maryland to Florida, including Washington, DC). ${ }^{8}$

The Census asks, when did this person come to the United States to stay? The census does not ask the type of visa used to enter the United States or whether permanent resident status was obtained. Given that many Soviet Jews entered the United States as asylees only to become permanent resident aliens (immigrants) at a later date, the census question is more appropriate for this analysis than would be the year the respondent obtained permanent resident alien or immigrant status. Since few Soviet Jews subsequently left the United States to return to the former Soviet Union or go to a third country, such as Israel, the emigration from the United

\footnotetext{
${ }^{7}$ Negative earnings can arise if the net losses from self-employment exceed the positive earnings from wages and salaries.

8 "Rural residence" is defined as living on a farm in the 2000 Census analysis and living in a rural area (farm or non-farm) in the 1980 and 1990 Census analyses.
} 
States of Soviet immigrants does not pose a selectivity problem (Ahmed and Robinson, 1994, and Mulder 2003). ${ }^{9}$

Variables for duration in the United States are central to the analysis and they are entered as period of arrival dichotomous variables. ${ }^{10}$ This specification was chosen to permit a finer determination of non-linearities than would a quadratic specification of a continuous duration variable. Moreover, it increases comparability with earlier research on Soviet Jews in the United States. When duration is held constant, the age variable reflects the effect of age at migration on English language proficiency.

Another key variable is country of birth. A person born in any of the republics that constituted the former Soviet Union (other than those who reported Armenian ancestry or language or the Ukrainian language), is considered to be a Soviet Jewish immigrant (FSU). ${ }^{11}$ Data are not available on when the person left the former Soviet Union or on country of last permanent residence, so it is not possible to identify whether there was a destination prior to coming to the U.S. In this analysis the country categories Europe and Asia constitute all of Europe and Asia, other than the designated parts of the former Soviet Union. Other country of

9 Tolts (2004a) also finds a very low re-migration rate of Soviet Jewish immigrants who arrive in Israel.

${ }^{10}$ The period of arrival categories used here are: 1996-2000, 1991-1995, 1987-1990, 1985-1986, 1980-1984, 1975-1979, 1970-1974, and 1965-1969. For the proportion of the sample who arrived in each interval, see Appendix, Table A-4.

${ }^{11}$ In the 2000 Census, unlike previous censuses, there are republic of birth codes for each of the 15 republics in the former Soviet Union, as well as a generic "USSR" code. Excluding those reporting Armenian by ancestry or language or that they speak Ukrainian at home, 46 percent reported the Russian Republic, 29 percent the Ukraine, 6 percent the USSR, 5 percent Belarus, and 14 percent reported having been born in the other 12 republics (Appendix Table A-3). In the post-World War II censuses until 2000 only the three Baltic Republics (Estonia, Latvia and Lithuania) were separately identified from the rest of the Soviet Union because the U.S. State Department did not recognize their incorporation into the Soviet Union. 
origin groups are Canada, Latin America (including the Caribbean), and other countries (Africa, Oceania, etc.). Europe other than the FSU serves as the benchmark.

The econometric analysis of earnings is based on the human capital earnings function, modified for immigrant adjustment (Chiswick 1978). The natural logarithm of annual earnings in 1999 is regressed on years of schooling completed, years of potential labor market experience (age minus schooling minus 5 years), and its square, the natural logarithm of weeks worked, and dichotomous variables as defined above for being proficient in English, married spouse present, living in a rural area and living in a southern state. The same dichotomous variables are used, as defined above, for period of arrival and country of origin. Controlling for period of arrival, the labor market experience variable measures the effect on earnings in 1999 of experience in the country of origin.

\section{Econometric Analysis}

\section{a) Language - Soviet and Other Immigrants}

The results of the multiple regression analysis for adult males for the dependent variable, proficient in English, are reported in Tables 5 and 6. The variable is unity for those who speak only English at home or who speak another language but speak English very well or well, otherwise the English fluency variable is zero.

Table 5 reports the equation for all immigrants by sub-period and for the whole period 1965-2000. As shown in column (1), consistent with what has been found elsewhere for immigrants, English language proficiency increases with years of schooling (3.5 percentage points more are proficient for each extra year of schooling). Proficiency is lower for those who immigrated at an older age. Five years older at immigration is equivalent to about one fewer year 
of schooling. Men who are married are more proficient (by 4 percentage points), but children at home detracts from their proficiency (by 2.6 percentage points per child).

Duration in the United States has a major impact on English language proficiency. The coefficients are highly statistically significant and show a consistent gradient of increased proficiency with duration in the U.S., with the effect of an extra year in the United States becoming smaller the longer the duration of residence. With those who immigrated in 1980-84 as the benchmark, other variables the same, the most recent immigrants (1996-2000) were 24 percentage points less proficient in 2000, or the equivalent of the effect 7 years of schooling. The earliest cohort, 1965-69 immigrants, was 12 percentage points more proficient than the 1996-2000 cohort or the equivalent of 3.5 years of schooling.

Other variables the same, Soviet immigrants are about 10.4 percentage points less likely to be proficient in English than other European immigrants. They are even less proficient than Asian immigrants (Asians are at a 7.7 percentage points disadvantage compared to European immigrants), but less disadvantaged than those from Latin America (17.3 percentage point differential compared to European immigrants).

It is possible to test whether the effect of duration in the U.S. on proficiency in English differs between Soviet and other immigrants. The statistical analysis (Table 5, column 2) shows that during the first four years the negative effect on proficiency of being an immigrant is much greater for Soviet Jews than it is for other immigrants. Compared to other recent European immigrants, Soviet Jews who arrived in 1995 to 2000 are 20 percentage points less proficient $(-0.1050-0.0908=0.20)$. Soviet Jews experience a steeper improvement in proficiency with duration in the U.S. so that the disadvantage is only 5.5 percentage points $(-0.1050+0.0502=0.055)$ for those who immigrated in 1990-94 (6 to 10 years in the U.S.) and 4.8 
percentage points $(-0.1050+0.0574=-0.048)$ for those who immigrated $1985-89$ (11 to 15 years in the U.S.). Indeed, the very large proportion of Soviet immigrants in the U.S. a short period of time and the very low English proficiency of this group are very important determinants of the overall low proficiency among Soviet immigrants.

The analysis was also performed for sub-periods within the 1965-2000 period (Table 5). For each of these sub-periods the effects of schooling, age at immigration, marital status and children are quite similar. ${ }^{12}$ That is, their partial effects on proficiency in 2000 do not appear to vary by period of immigration. The effects of duration do vary by period of immigration. One fewer year in the U.S. has a larger negative effect on proficiency the more recently the immigrant cohort arrived in the U.S., which is consistent with the non-linear effect of duration on proficiency.

The results reported here for the 2000 Census can be compared with analyses reported previously for Soviet Jews and other immigrants who came to the U.S. in 1965 or later using the microdata files from the 1980 and 1990 Censuses (Chiswick 1993, 1997) (see Table 6). The effects on English language proficiency of schooling, age, marital status, and rural residence are virtually identical across the three censuses, although the positive effect of being married was much smaller in the 1980 Census and the positive effects of living in the South is smaller in 2000 than in 1990. ${ }^{13}$ The negative effects of children in the household are also smaller in absolute value in 2000 than in 1990, but it was not significant in 1980. The strong positive effect of duration in the U.S. on proficiency is also observed in these earlier censuses.

\footnotetext{
${ }^{12}$ A notable exception is the much larger positive effect of being married in the most recent cohort, 1990 to 2000.

${ }^{13}$ For a discussion of the regional distribution of immigrants and their language skills, see Chiswick and Miller (2005).
} 
The 10 percentage point disadvantage of being from the former Soviet Union compared to another part of Europe in the 2000 data is somewhat smaller than the 14 percentage points in the 1980 and 1990 Censuses. When the interaction terms of Soviet origin with duration are added, the Soviet intercept is a highly significant minus 5 percentage points in 2000, compared to a non-significant positive 3 percentage points in 1990. The negative effect of being in a particular immigrant cohort compared to an earlier arrival cohort diminishes from the 1980 to the 2000 Census as the cohorts are in the U.S. a longer period of time. Most striking is that in 1990 the only Soviet-duration of residence interaction term whose coefficient was large or statistically different from the benchmark (1980-84) was the most recent cohort, 1987-90 (coefficient of minus 25 percentage points). Ten years later, compared to the same benchmark, the 1987-90 interaction term has a coefficient of only 3 percentage points and it is not statistically significant.

These results suggest that the sharp gradient of English language proficiency with duration in the U.S. is not a consequence of declining proficiency among more recent cohorts. Rather it appears to be reflecting a longitudinal or adjustment effect, that is, the acquisition of English language proficiency as a cohort has a longer duration in the U.S. Moreover, this initial deficiency and speed of adjustment (improvement) appear to be more intense for Soviet Jews than for other immigrants. This may reflect their refugee motivated migration, the limited ability to prepare for the emigration because of the arbitrary nature of the Soviet bureaucracy, and the unexpected and sudden opening for emigration from the Soviet Union, with uncertainty as to how long emigration would be possible.

\section{(b) Earnings - Soviet and Other Immigrants}

The analysis of earnings (Table 7, Column 1) indicates that an extra year of schooling raises the earnings of immigrants by about 4.6 percent, that earnings increase at a decreasing rate 
with an increase in total labor market experience, that earnings rise by about 0.85 percent for each one percent increase in weeks worked (about one half of a week), and that earnings increase with duration of residence in the U.S. Indeed, compared to those who immigrated in 1980-84, those who recently arrived (immigrated 1996-2000) have about 16 percent lower weekly earnings, while those who immigrated in 1965 to 1969 had about 11 percent higher weekly earnings.

The effects of country of origin are quite large. Compared to European immigrants, those from the Soviet Union had weekly earnings that were nearly 20 percent lower, other measured variables being the same. Only Latin American immigrants had a larger earnings disadvantage (about 32 percent) compared to those from Europe, while Canadian immigrants showed a large earnings advantage over Europeans (about 13 percent). Other factors that resulted in higher earnings are being proficient in English (about 17 percent), being married (21 percent), living in an urban area (8 percent) and living outside the south (3 percent).

Other variables the same, as shown in Table 7, column 2, an extra year of schooling is associated with 7.0 percent higher earnings for the Soviet Jewish immigrants, in contrast to the 4.6 percent for other immigrants, and the difference is highly statistically significant ( $\mathrm{t}=11.0)$. Also, other things the same, the earnings of Soviet Jewish immigrants are much lower (and the difference is highly significant) than those of other immigrants who came in the same time period during the first few years in the U.S. (immigrated 1996-2000 or 1991-1995). The magnitude diminishes but does not disappear for those who have been in the United States for ten or more years in 2000.

Thus, the earnings gap between Soviet and other immigrants varies with duration in the U.S. and level of schooling. At the mean level of schooling of Soviet immigrants (14.8 years), 
those who immigrated in 1980 to 1984 (16 to 20 years in the U.S.) had about 5 percent higher weekly earnings than other European immigrants (the partial effect is: $-0.3106+(14.8)(0.0244)$ $=0.051)$.

The comparison of these results with the 1990 and 1980 Census analyses is striking (Chiswick 1997) (Table 8). In 1990 the effect of schooling on earnings was larger for Soviet Jewish immigrants by 1.9 percentage points, in 1980 by 2.8 percentage points, and in 2000 by 2.6 percentage points, all of which were significantly different from zero, but not from each other. In 1990 the Soviet immigrant duration of residence interaction term for the most recent arrivals was large and highly significant compared to the benchmark (1980-84 cohort), as was the case in 1980 (1970-74 benchmark), but the differential shrank with duration. Although only in the U.S. 6 to 10 years at the time of the 1990 Census, at the mean level of schooling for Soviet immigrants (14.9 years), the earnings of the 1980-84 cohort of Soviet Jews was only one percent lower than that of other European immigrants. As in the 2000 Census, the larger return from schooling narrowed the earnings gap between Soviet Jews and other immigrants in spite of a larger initial earnings disadvantage.

Among the Soviet immigrants (Table 8), the 31 percent greater earnings disadvantage of the 1987-90 cohort compared to the 1984-85 cohort in 1990, shrank to a marginally significant (t = 1.6) 14 percent disadvantage ten years later in 2000. This too suggests that what is being observed is an immigrant assimilation process rather than a change (deterioration) in the earnings potential of more recent cohorts.

For most of the other explanatory variables their partial effects on earnings did not change by much across the three censuses. Perhaps the most dramatic change is the increase in 
the negative effects of living in a rural area. This may be due to the change in the definition of rural from the old census definition of rural (farm and non-farm) to only those living on a farm.

Moreover, the lower initial earnings and the steeper rise in earnings with duration of residence in the U.S. of the Soviet Jewish immigrants, compared with other immigrant groups, is a phenomenon to be expected among refugee populations. Since their motives for migrating are not strictly economic, refugees tend to be less prepared for the move, especially Soviet migrants, and to have skills that are less readily transferable to the destination.

\section{(c) Language and Earnings - Soviet Jewish Immigrants}

Parallel analyses to those reported above were performed separately for just the Soviet Jewish immigrants (Appendix Tables A-5 and A-6). The statistical significance of many of the variables is reduced because of the much smaller sample size. Of particular interest is whether there are differences among Soviet immigrants depending on their reported ethnic ancestries. Excluding those of Armenian ancestry or language and Ukrainian language, four groups are defined, Russian (53 percent of the sample), Ukrainian (18 percent), a response that revealed a person's religion (12 percent), and all other responses (17 percent). Those of Russian ancestry serve as the benchmark. The coefficients and significance levels of the other variables do not change when the ethnic ancestry variables are entered into the equation.

In the language analysis, other variables the same, few differences are found in English language proficiency by ancestry (Appendix Table A-5). Those of Ukrainian origin are 2 percentage points less proficient in English than those of Russian ancestry, but the difference is at the margin of being significant $(\mathrm{t}=1.7)$. Those of "other ancestries" are one percentage point less proficient than the Russians, but this is not statistically significant $(t=0.7)$. There is no 
difference from those of Russian ancestry among those who gave a response indicating their religion (the coefficient indicates a 2.5 percentage point higher proficiency with $t=1.8$ ).

The analysis of earnings, other variables being the same, presents a similar picture (Appendix Table A-6). For the post-1965 immigrants, there is no difference in earnings between the Russian, Ukrainian and religious revealing ancestries. Compared to the Russians, the Ukrainians had 2.1 percent lower earnings, but a $t=-0.7$, while those who gave a religious response had 4.5 percent higher earnings, but a $t=1.3$. Only the heterogeneous group of "other ancestries” showed an earnings differential, a marginally significant $(t=1.9) 5.5$ percent higher earnings.

The coefficient on the education variable in the earnings analysis limited to Soviet Jewish immigrants is about 7.3 percent, whether or not the Soviet ancestry variables are held constant. This is a very large coefficient for an immigrant population in the United States and is significantly greater than for other immigrants. That it does not change when ancestry is held constant suggests that it holds across the ancestry groups that in this study are used to identify Soviet Jews.

\section{Summary and Conclusion}

This paper has been concerned with the English language proficiency and labor market earnings of adult (age 25 to 64 years) male Soviet Jews who immigrated to the United States since 1965. The data for the empirical analysis are from the 2000 Census of Population, Public Use Microdata Sample, and is for a five percent sample of the population. Comparisons are made to earlier parallel analyses using the 1980 and 1990 Censuses. Because of the absence of direct information on who is Jewish or of Jewish ancestry, the empirical analysis is based on 
persons born in the Former Soviet Union who are not of Armenian ancestry and do not speak Armenian or Ukrainian at home. This definition should capture most Soviet Jews but include few non-Jewish immigrants from the former Soviet Union.

The Soviet Jews were less proficient in English than other European and Asian immigrants. Under the definition of proficiency used in this study, 72 percent of the Soviet Jews were proficient, compared to 89 percent for European immigrants, 82 percent for Asian immigrants and 57 percent for those from Latin America. Their earnings (at $\$ 37,600$ in 1999) were considerably less than the earnings of other European $(\$ 50,900)$ and Asian immigrants $(\$ 42,400)$, but were greater than the earnings of Latin American immigrants $(\$ 23,000)$.

The much higher level of schooling of the Soviet immigrants would tend to enhance their English proficiency and earnings; 14.8 years for the Soviet Jews, compared to 14.1 for Asian immigrants, 13.6 years for European immigrants, and 9.3 years for Latin American immigrants. On the other hand, the refugee motivations for their move and their recency of arrival would tend to lower their English language skills and earnings. Among those who immigrated since 1965, 70 percent of the Soviet Jewish migrants were in the United States ten or fewer years, compared to only 37 percent of those from Europe, 37 percent of the Asians and 35 percent of the Latin Americans.

Multiple regression analysis is used to examine the effects of being a Soviet Jewish immigrant compared to coming from another region, when all other measured variables are held constant. It is found that recently arrived Soviet immigrants have a lower level of English proficiency than other European immigrants, but they have a faster rate of improvement with duration in the U.S. As a result the difference virtually disappears for those in the United States 16 to 20 years. The 1980 and 1990 Census data analyses show a similar pattern for recent 
immigrants. This appears to be a longitudinal phenomenon reflecting their refugee experience, rather than inherently poorer English proficiency that will persist among the most recent cohorts.

Thus, the low level of English proficiency among Soviet immigrants is due to the low proficiency among recent arrivals and the large proportion that recently arrived. It is a temporary and not a permanent phenomenon.

The analysis of earnings, other measured variables the same, also shows much lower earnings among recent Soviet Jewish immigrants, but a steeper improvement with duration in the United States. The Soviet immigrants have a much larger positive effect of schooling on earnings compared to other immigrants. An extra year of schooling raises the earnings of Soviet Jewish immigrants by about 7.3 percent, compared to only 4.6 percent for other immigrants. As a result there is an earnings catch-up coming sooner the higher the level of schooling. Similar patterns were found in the analyses for the 1980 and 1990 Censuses.

Again, this suggests that the earnings disadvantage of Soviet Jewish immigrants as a group is short-lived and is due to the low earnings of recent arrivals and the disproportionate number of recent arrivals in the 2000 Census.

Analyses of English language proficiency and earnings were also performed for those classified here as Soviet Jewish immigrants by the ancestry they reported in the 2000 Census: Russian, Ukrainian, an ancestry response that reveals one's religion, and all other ancestry responses. In the language analysis, there was essentially no difference in English proficiency, other variables the same, between those of Russian and "other ancestries", although those who indicated Ukrainian had slightly lower proficiency while those who indicated a religion were marginally more proficient. In the earnings analysis, other variables the same, there were no significant differences among these three groups, although the heterogeneous group of other 
ancestries showed a marginally significant 5 percent earnings advantage. The addition of ancestry variables to the language and earnings equations does not alter the effect of schooling.

Overall, it appears that Soviet Jewish immigrants adjust very well in the United States compared to other European immigrants. Their initial disadvantages in English language skills and earnings may be due to the refugee motivations for migration. ${ }^{14}$ With the passage of time this disadvantage disappears. For earnings it disappears most rapidly for those with higher levels of schooling. This very high level of schooling and the greater effect of schooling on earnings among Soviet Jewish immigrants compared to other immigrants parallels patterns found among Jews and non-Jews born in the U.S. (Chiswick, 1999). Thus, the Soviet Jews appear to be reflecting patterns that are specific to both refugees and Jews in the United States.

${ }^{14}$ Lower initial English proficiency and earnings and a speedier improvement appear to be a general refugee phenomenon, although not the larger payoff from schooling (see Chiswick 1978, 1979 and Chiswick and Miller 1998). 


\section{REFERENCES}

Ahmed, Bashir and J. Gregory Robinson (1994). "Estimates of Emigration of the Foreign-Born Population: 1980-1990," U.S. Bureau of the Census, Population Division Technical Working Paper No. 9.

Bernstein, Richard (2005). "Policy Shifts in Germany Trims Jewish Migration," New York Times, February 20, 2005.

Chiswick, Barry R. (1978). "The Effect of Americanization on the Earnings of Foreignborn Men,” Journal of Political Economy, 86(5), October, pp. 897-922.

Chiswick, Barry R. (1979). "The Economic Progress of Immigrants: Some Apparently Universal Patterns,” in William Fellner, ed., Contemporary Economic Problems, 1979, Washington: American Enterprise Institute, pp. 357-399.

Chiswick, Barry R. (1988). "Hebrew Language Usage: Determinants and Effects on Earnings Among Immigrants in Israel,” Journal of Population Economics, 11(2), May, pp. 253271.

Chiswick, Barry R. (1991). "Jewish Immigrant Skill and Occupational Status at the Turn of the Century” Explorations in Economic History, 28(1), January, pp. 64-86.

Chiswick, Barry R. (1992). "Jewish Immigrant Wages in America in 1909: An Analysis of the Dillingham Commission Data," Exploration in Economic History, 29(3), July pp. 274-289.

Chiswick, Barry R. (1993). "Soviet Jews in the United States: An Analysis of Their Linguistic and Economic Adjustment," International Migration Review, 27(2), Summer, pp. 260286.

Chiswick, Barry R. (1997). "Soviet Jews in the United States: Language and Labor Market Adjustments Revisited,” in Noah Lewin-Epstein, Yaacov Ro’i and Paul Ritterband, eds., Russian Jews on Three Continents: Migration and Resettlement, London: Frank Cass Publishers, pp. 233-260.

Chiswick, Barry R. (1999). "The Occupational Attainment and Earnings of American Jewry, 1890-1990,” Contemporary Jewry, 20, pp. 68-98.

Chiswick, Barry R. (2000). "Are Immigrants Favorably Self-Selected: An Economic Analysis," in Caroline D. Brettell and James F. Hollifield, eds. Migration Theory: Talking Across Disciplines, New York: Routledge, pp. 61-76.

Chiswick, Barry R. and Paul W. Miller (1998). "English Language Fluency Among Immigrants in the United States,” Research in Labor Economics, 17, pp. 151-200. 
Chiswick, Barry R. and Paul W. Miller (2005) "Do Enclaves Matter in Immigrant Adjustment?” City and Community, 4(1), March, pp. 5-35.

Chiswick, Barry R. and Gaston Repetto (2001) "Immigrant Adjustment in Israel: Literacy and Fluency in Hebrew and Earnings," in Slobodan Djajic, ed. International Migration: Trends, Policy and Economic Impact, New York: Routledge, pp. 204-228.

Glinert, Lewis H. (1995). “Inside the Language Planner’s Head: Tactical Responses to a Mass Immigration,” Journal of Multilingual and Multicultural Development, 16(5), pp. 351-372.

Karklins, Rasma (1987). "Determinants of Ethnic Identification in the USSR: The Soviet Jewish Case,” Ethnic and Racial Studies,10(1), January, pp. 27-47.

Mulder, Tammany J. (2003). "Foreign-born Emigration from the United States: 1990 to 2000,” Paper presented at the Population Association of America, Annual Meeting, Minneapolis, May.

Tolts, Mark (2004a). "Demographic Trends Among the Jews of the FSU," Paper presented at the International Conference on Soviet and Post-Soviet Jewry in Honor of Professor Mordechai Altshuler, Hebrew University, Jerusalem, December 28-30, 2003. Revised January 12, 2004.

Tolts, Mark (2004b). “The Post-Soviet Jewish Population in Russia and the World” Jews in Russia and Eastern Europe, No. 1(52), pp. 37-63.

Tress, Madeleine (1995). "Soviet Jews in the Federal Republic of Germany: The Rebuilding of a Community,” The Jewish Journal of Sociology, 37(1), pp. 39-54.

U.S. Bureau of the Census (2003). 2000 Census of Population and Housing, Public Use Microdata Sample, United States, Technical Documentation, Washington, D.C. 
Table 1

\section{Immigration to the United States from Russia and the Soviet Union, $1820-2002^{(a)}$}

\begin{tabular}{l|r} 
Time Period & Number of Immigrants \\
\hline $1820-30$ & 89 \\
$1831-40$ & 277 \\
$1841-50$ & 551 \\
$1851-60$ & 457 \\
$1861-70$ & 2,512 \\
$1871-80$ & 39,284 \\
$1881-90$ & 213,282 \\
$1891-1900$ & 505,290 \\
$1901-10$ & $1,597,306$ \\
$1911-20$ & 921,201 \\
$1921-30$ & 61,742 \\
$1931-40$ & 1,370 \\
$1941-50$ & 571 \\
$1951-60$ & 671 \\
$1961-70$ & 2,465 \\
$1971-80$ & 38,961 \\
$1981-90$ & 57,677 \\
$1991-2000$ & 462,874 \\
2001 & 55,099 \\
2002 & 55,464 \\
& \\
\hline Total & $4,017,129$
\end{tabular}

${ }^{(a)}$ Individuals granted permanent resident alien status. Includes all constituent units of the Russian Empire and of the Former Soviet Union.

Source: U.S. Department of Justice, 1993 Statistical Yearbook of the Immigration and Naturalization Service, Washington D.C., September 1994; U.S. Department of Justice, 2001 Statistical Yearbook of the Immigration and Naturalization Service, Washington D.C., February 2003; and U.S. Department of Homeland Security, 2002 Yearbook of Immigration Statistics, Washington D.C., October 2003. 
Table 2

Soviet Refugee and Asylee Arrivals and Admissions, FY 1961-2002

\begin{tabular}{|c|c|c|}
\hline Year & Dept of Justice ${ }^{(a)}$ & Dept of State ${ }^{(b)}$ \\
\hline 1961-69 & 456 & \\
\hline 1970 & 209 & \\
\hline 1971 & 88 & \\
\hline 1972 & 228 & \\
\hline 1973 & 591 & \\
\hline 1974 & 2,221 & \\
\hline 1975 & 3,209 & 6,211 \\
\hline 1976 & 5,882 & 7,450 \\
\hline TQ 1976 & 1,208 & \\
\hline 1977 & 5,296 & 8,191 \\
\hline 1978 & 9,931 & 10,688 \\
\hline 1979 & 27,135 & 24,449 \\
\hline 1980 & 28,692 & 28,444 \\
\hline 1981 & 11,244 & 13,444 \\
\hline 1982 & 2,838 & 2,756 \\
\hline 1983 & 1,449 & 1,409 \\
\hline 1984 & 791 & 715 \\
\hline 1985 & 674 & 640 \\
\hline 1986 & 833 & 787 \\
\hline 1987 & 3,728 & 3,694 \\
\hline 1988 & 18,880 & 20,421 \\
\hline 1989 & 39,831 & 39,553 \\
\hline 1990 & 53,130 & 50,716 \\
\hline 1991 & 57,587 & 38,661 \\
\hline 1992 & 66,026 & 61,298 \\
\hline 1993 & 51,983 & 48,627 \\
\hline 1994 & NA & 43,470 \\
\hline 1995 & NA & 35,716 \\
\hline 1996 & NA & 29,536 \\
\hline 1997 & NA & 27,072 \\
\hline 1998 & NA & 23,349 \\
\hline 1999 & NA & 17,220 \\
\hline 2000 & NA & 15,103 \\
\hline 2001 & NA & 15,749 \\
\hline 2002 & NA & 23,150 \\
\hline Total & 394,140 & 598,519 \\
\hline
\end{tabular}

(a)Soviet refugee and asylee approvals, fiscal year 1961-1993. TQ1976 means transition quarter when fiscal year was adjusted to start October 1 rather than July 1.

(b)Refugee admissions from the Soviet Union, 1976-2002, including all republics from the former Soviet Union.

Source: U.S. Department of Justice, 2001 Statistical Yearbook of the Immigration and NaturalizationService, Washington, DC, February 2003, Table 24. U.S. Department of Homeland Security, Yearbook of Immigration Statistics, 2002, Washington, DC, October, 2003. 
Table 3

Selected Characteristics of Adult Males Who Immigrated Since 1965 by Region of Birth, 2000

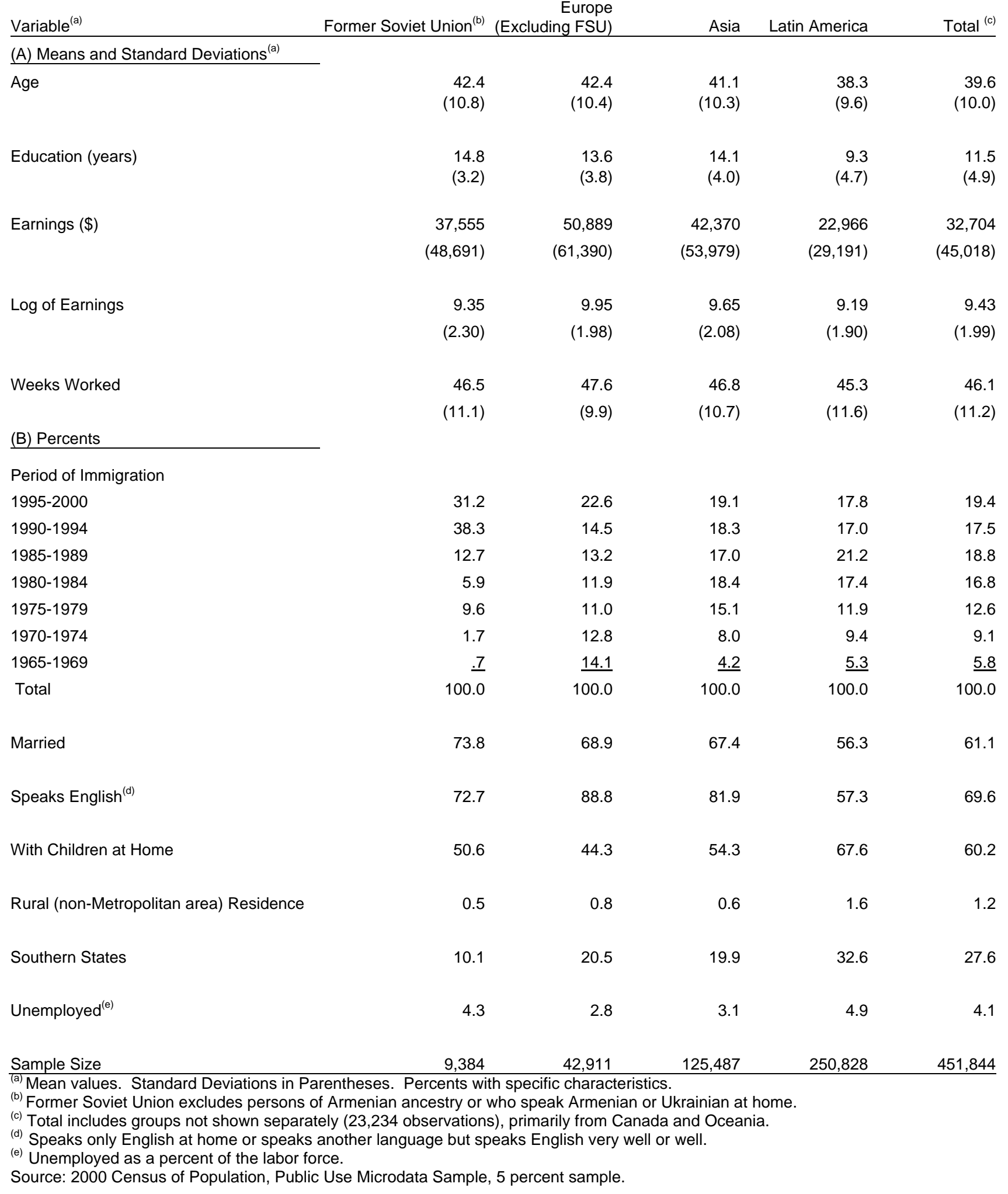


Table 4

Fluency in English Among Adult Male Immigrants Who Immigrated Since 1965 by Region of Origin ${ }^{(a)}$ (percent)

\begin{tabular}{rrrrrr}
\hline $\begin{array}{r}\text { English } \\
\text { Fluency }\end{array}$ & $\begin{array}{r}\text { Former } \\
\text { Soviet } \\
\text { Union }^{(\text {b) }}\end{array}$ & $\begin{array}{r}\text { Europe } \\
\text { (Excluding } \\
\text { FSU) }\end{array}$ & Asia & $\begin{array}{r}\text { Latin } \\
\text { America }\end{array}$ & All \\
\hline $\begin{array}{r}\text { Speaks only } \\
\text { English at home }\end{array}$ & 4.5 & 32.3 & 7.4 & 10.7 & 13.4 \\
\hline $\begin{array}{r}\text { Speaks another } \\
\text { Language at }\end{array}$ & & & & & \\
home and speaks & & & & & \\
English: & 30.1 & 36.6 & 45.3 & 22.0 & 31.1 \\
Very Well & 37.8 & 19.9 & 29.4 & 24.6 & 25.1 \\
Well & 22.5 & 9.6 & 15.4 & 28.2 & 21.4 \\
Not Well & 4.3 & 1.6 & 2.5 & 14.5 & 9.0 \\
Not at All & 100.0 & 100.0 & 100.0 & 100.0 & 100.0 \\
Total & & & & & \\
& 8,373 & 42,590 & 124,735 & 250,826 & 451,844 \\
\hline
\end{tabular}

(a) All immigrants include groups not shown separately.

(b) Former Soviet Union excludes persons of Armenian ancestry and persons who speak Armenian or Ukrainian at home.

Note: Detail may not add to total due to rounding.

Source: 2000 Census of Population, Public Use Microdata Sample, 5 percent sample. 
Table 5

Regression Analysis of Fluency in English among Adult Males who Immigrated since 1965: 2000 Dependent Variable=ZENGSPK 2000 Census

\begin{tabular}{|c|c|c|c|c|c|c|c|c|}
\hline \multirow{2}{*}{$\begin{array}{l}\text { Immigration } \\
\text { Period: } \\
\text { Variable } \\
\end{array}$} & \multicolumn{2}{|c|}{$1965-2000$} & \multicolumn{2}{|c|}{$1965-1979$} & \multicolumn{2}{|c|}{$1980-1989$} & \multicolumn{2}{|c|}{$1990-2000$} \\
\hline & (1) & (2) & (1) & (2) & (1) & (2) & (1) & (2) \\
\hline CONSTANT & $\begin{array}{r}.7238 \\
(169.12)\end{array}$ & $\begin{array}{r}.7241 \\
(169.07)\end{array}$ & $\begin{array}{r}.7980 \\
(114.50)\end{array}$ & $\begin{array}{r}.7980 \\
(114.50)\end{array}$ & $\begin{array}{r}.7618 \\
(94.72)\end{array}$ & $\begin{array}{r}.7615 \\
(94.69)\end{array}$ & $\begin{array}{r}.6048 \\
(89.67)\end{array}$ & $\begin{array}{r}.6063 \\
(89.89)\end{array}$ \\
\hline EDUCYRS & $\begin{array}{r}.0349 \\
(255.53)\end{array}$ & $\begin{array}{r}.0349 \\
(255.37)\end{array}$ & $\begin{array}{r}.0335 \\
(150.77)\end{array}$ & $\begin{array}{r}.0335 \\
(150.74)\end{array}$ & $\begin{array}{r}.0363 \\
(147.89)\end{array}$ & $\begin{array}{r}.0363 \\
(147.87)\end{array}$ & $\begin{array}{r}.0342 \\
(139.85)\end{array}$ & $\begin{array}{r}\mathbf{0 3 4 2} \\
(139.83)\end{array}$ \\
\hline AGE & $\begin{array}{r}-.0067 \\
(-99.89)\end{array}$ & $\begin{array}{r}-.0067 \\
(-100.05)\end{array}$ & $\begin{array}{r}-.0068 \\
(-61.96)\end{array}$ & $\begin{array}{r}-.0068 \\
(-61.94)\end{array}$ & $\begin{array}{r}-.0079 \\
(-62.49)\end{array}$ & $\begin{array}{r}-.0079 \\
(-62.50)\end{array}$ & $\begin{array}{r}-.0056 \\
(-49.66)\end{array}$ & $\begin{array}{r}-.0057 \\
(-49.82)\end{array}$ \\
\hline IM95_00 & $\begin{array}{r}-.2405 \\
(-120.21)\end{array}$ & $\begin{array}{r}-.2380 \\
(-118.47)\end{array}$ & & & & & $\begin{array}{r}-.1041 \\
(-50.05)\end{array}$ & $\begin{array}{r}-.1006 \\
(-47.84)\end{array}$ \\
\hline IM90_94 & $\begin{array}{r}-.1396 \\
(-68.98)\end{array}$ & $\begin{array}{r}-.1415 \\
(-69.46)\end{array}$ & & & & & * & * \\
\hline IM85_89 & $\begin{array}{r}-.0631 \\
(-31.99)\end{array}$ & $\begin{array}{r}-.0637 \\
(-32.24)\end{array}$ & & & $\begin{array}{r}-.0614 \\
(-28.54)\end{array}$ & $\begin{array}{r}-.0617 \\
(-28.60)\end{array}$ & & \\
\hline IM75_79 & $\begin{array}{r}.0573 \\
(26.28)\end{array}$ & $\begin{array}{r}.0571 \\
(26.08)\end{array}$ & $\begin{array}{r}-.0382 \\
(-17.28)\end{array}$ & $\begin{array}{r}-.0381 \\
(-17.20)\end{array}$ & & & & \\
\hline IM70_74 & $\begin{array}{r}.0958 \\
(39.38)\end{array}$ & $\begin{array}{r}.0959 \\
(39.38)\end{array}$ & * & * & & & & \\
\hline IM65_69 & $\begin{array}{r}.1230 \\
(42.54)\end{array}$ & $\begin{array}{r}.1232 \\
(42.57)\end{array}$ & $\begin{array}{r}.0381 \\
(14.19)\end{array}$ & $\begin{array}{r}.0382 \\
(14.21)\end{array}$ & & & & \\
\hline IM95_00*FSUJEW & & $\begin{array}{l}-.0908 \\
(-7.64)\end{array}$ & & & & & & $\begin{array}{r}-.1118 \\
(-10.15)\end{array}$ \\
\hline IM90_94*FSUJEW & & $\begin{array}{l}.0502 \\
(4.46)\end{array}$ & & & & & & \\
\hline IM85_89*FSUJEW & & $\begin{array}{l}.0574 \\
(3.70)\end{array}$ & & & & $\begin{array}{l}.0494 \\
(1.89)\end{array}$ & & \\
\hline IM75_79*FSUJEW & & $\begin{array}{l}.0182 \\
(1.10)\end{array}$ & & $\begin{array}{l}-.0202 \\
(-0.89)\end{array}$ & & & & \\
\hline IM70_74*FSUJEW & & $\begin{array}{l}-.0021 \\
(-0.06)\end{array}$ & & * & & & & \\
\hline IM65_69*FSUJEW & & $\begin{array}{l}.0066 \\
(0.12)\end{array}$ & & $\begin{array}{l}-.0436 \\
(-0.87)\end{array}$ & & & & \\
\hline MARRSP & $\begin{array}{r}.0409 \\
(29.96)\end{array}$ & $\begin{array}{r}.0410 \\
(30.09)\end{array}$ & $\begin{array}{l}.0220 \\
(9.53)\end{array}$ & $\begin{array}{l}.0220 \\
(9.53)\end{array}$ & $\begin{array}{r}.0264 \\
(10.53)\end{array}$ & $\begin{array}{r}.0264 \\
(10.53)\end{array}$ & $\begin{array}{r}.0537 \\
(23.08)\end{array}$ & $\begin{array}{r}.0539 \\
(23.15)\end{array}$ \\
\hline RURAL & $\begin{array}{l}.0082 \\
(1.55)\end{array}$ & $\begin{array}{l}.0082 \\
(1.56)\end{array}$ & $\begin{array}{l}.0139 \\
(1.52)\end{array}$ & $\begin{array}{l}.0139 \\
(1.52)\end{array}$ & $\begin{array}{l}.0142 \\
(1.47)\end{array}$ & $\begin{array}{l}.0142 \\
(1.48)\end{array}$ & $\begin{array}{l}.0075 \\
(0.86)\end{array}$ & $\begin{array}{l}.0075 \\
(0.85)\end{array}$ \\
\hline SOUTH & $\begin{array}{l}.0081 \\
(6.08)\end{array}$ & $\begin{array}{l}.0080 \\
(6.02)\end{array}$ & $\begin{array}{l}.0094 \\
(4.25)\end{array}$ & $\begin{array}{l}.0094 \\
(4.25)\end{array}$ & $\begin{array}{l}.0166 \\
(6.83)\end{array}$ & $\begin{array}{l}.0166 \\
(6.82)\end{array}$ & $\begin{array}{l}.0041 \\
(1.83)\end{array}$ & $\begin{array}{l}.0041 \\
(1.80)\end{array}$ \\
\hline CHILD & $\begin{array}{r}-.0257 \\
(-19.19)\end{array}$ & $\begin{array}{r}-.0255 \\
(-19.05)\end{array}$ & $\begin{array}{l}-.0086 \\
(-3.94)\end{array}$ & $\begin{array}{l}-.0086 \\
(-3.94)\end{array}$ & $\begin{array}{l}-.0201 \\
(-7.83)\end{array}$ & $\begin{array}{l}-.0201 \\
(-7.84)\end{array}$ & $\begin{array}{r}-.0400 \\
(-17.64)\end{array}$ & $\begin{array}{r}.0398 \\
(-17.52)\end{array}$ \\
\hline FSU & $\begin{array}{r}-.1043 \\
(-23.85)\end{array}$ & $\begin{array}{r}-.1050 \\
(-12.44)\end{array}$ & $\begin{array}{l}-.0276 \\
(-2.69)\end{array}$ & $\begin{array}{l}-.0118 \\
(-0.61)\end{array}$ & $\begin{array}{l}-.0390 \\
(-3.07)\end{array}$ & $\begin{array}{l}-.0555 \\
(-3.61)\end{array}$ & $\begin{array}{r}-.1733 \\
(-29.65)\end{array}$ & $\begin{array}{r}.1354 \\
(-19.53)\end{array}$ \\
\hline ASIA & $\begin{array}{r}-.0766 \\
(-35.26)\end{array}$ & $\begin{array}{r}-.0764 \\
(-34.58)\end{array}$ & $\begin{array}{r}-.0658 \\
(-20.19)\end{array}$ & $\begin{array}{r}-.0660 \\
(-20.19)\end{array}$ & $\begin{array}{r}-.0907 \\
(-20.10)\end{array}$ & $\begin{array}{r}-.0902 \\
(-19.94)\end{array}$ & $\begin{array}{r}-.0804 \\
(-21.72)\end{array}$ & $\begin{array}{r}.0839 \\
(-22.58)\end{array}$ \\
\hline LATAMER & $\begin{array}{r}-.1725 \\
(-79.66)\end{array}$ & $\begin{array}{r}-.1723 \\
(-78.95)\end{array}$ & $\begin{array}{r}-.0911 \\
(-29.53)\end{array}$ & $\begin{array}{r}-.0913 \\
(-29.54)\end{array}$ & $\begin{array}{r}-.1622 \\
(-35.95)\end{array}$ & $\begin{array}{r}-.1618 \\
(-35.81)\end{array}$ & $\begin{array}{r}-.2562 \\
(-66.94)\end{array}$ & $\begin{array}{r}.2588 \\
(-67.49)\end{array}$ \\
\hline CANADA & $\begin{array}{r}.0705 \\
(14.45)\end{array}$ & $\begin{array}{r}.0704 \\
(14.42)\end{array}$ & $\begin{array}{l}-.0015 \\
(-0.21)\end{array}$ & $\begin{array}{l}-.0017 \\
(-0.23)\end{array}$ & $\begin{array}{l}.0397 \\
(3.57)\end{array}$ & $\begin{array}{l}.0401 \\
(3.61)\end{array}$ & $\begin{array}{r}.1263 \\
(15.99)\end{array}$ & $\begin{array}{r}.1234 \\
(15.62)\end{array}$ \\
\hline OTHER & $\begin{array}{r}.0584 \\
(16.59)\end{array}$ & $\begin{array}{r}.0584 \\
(16.53)\end{array}$ & $\begin{array}{l}-.0052 \\
(-0.86)\end{array}$ & $\begin{array}{l}-.0054 \\
(-0.89)\end{array}$ & $\begin{array}{l}.0195 \\
(2.79)\end{array}$ & $\begin{array}{l}.0199 \\
(2.85)\end{array}$ & $\begin{array}{r}.0882 \\
(15.62)\end{array}$ & $\begin{array}{r}.0854 \\
(15.11)\end{array}$ \\
\hline
\end{tabular}




\begin{tabular}{rrrrrrrrr} 
SAMPLE SIZE & 451843 & 451843 & 124512 & 124512 & 140887 & 140887 & 166684 & 166684 \\
STANDARD & .3925 & .3924 & .3344 & .3344 & .3983 & .3983 & .4178 & .4176 \\
ERROR & & & & & & & & \\
R2 & .2723 & .2726 & .2586 & .2586 & .2299 & .2299 & .2739 & .2744 \\
ADJUSTED R2 & .2722 & .2725 & .2585 & .2585 & .2298 & .2298 & .2739 & .2743 \\
\hline
\end{tabular}

t-ratios in parentheses.

*omitted as benchmark; 1980-1984 and EUROPE are benchmarks unless otherwise noted.

Source: 2000 U.S. Census of Population, Public Use Microdata Sample, 5\% Sample 
Table 6

Regression Analysis of English Fluency Among Adult Males Who Immigrated Since 1965: 2000, 1990, 1980 Dependent Variable=ENGSPK

\begin{tabular}{|c|c|c|c|c|c|}
\hline $\begin{array}{l}\text { Immigration Period: } \\
\text { Variable }\end{array}$ & $\begin{array}{c}2000 \mathrm{C} \\
1965 \\
(1)\end{array}$ & $\begin{array}{l}\text { nsus } \\
2000 \\
\end{array}$ & $\begin{array}{r}1990 \\
19 \\
(1)\end{array}$ & $\begin{array}{l}\text { nsus } \\
1989 \\
\end{array}$ & $\begin{array}{l}1980 \text { Census } \\
1965-1979 \\
(1)\end{array}$ \\
\hline CONSTANT & $\begin{array}{r}.7177 \\
(74.75)\end{array}$ & $\begin{array}{r}.7188 \\
(74.87)\end{array}$ & $\begin{array}{r}.6031 \\
(114.99)\end{array}$ & $\begin{array}{r}.6027 \\
(114.94)\end{array}$ & $\begin{array}{r}.5243 \\
(41.60)\end{array}$ \\
\hline EDUCYRS & $\begin{array}{r}.0347 \\
(113.15)\end{array}$ & $\begin{array}{r}.0347 \\
(113.12)\end{array}$ & $\begin{array}{r}.0356 \\
(192.66)\end{array}$ & $\begin{array}{r}.0355 \\
(192.59)\end{array}$ & $\begin{array}{r}.0388 \\
(89.92)\end{array}$ \\
\hline AGE & $\begin{array}{r}-.0066 \\
(-44.38)\end{array}$ & $\begin{array}{r}-.0067 \\
(-44.49)\end{array}$ & $\begin{array}{r}-.0067 \\
(-73.07)\end{array}$ & $\begin{array}{r}-.0067 \\
(-73.30)\end{array}$ & $\begin{array}{r}-.0050 \\
(-20.26)\end{array}$ \\
\hline IM96_00 & $\begin{array}{r}-.2492 \\
(-52.88)\end{array}$ & $\begin{array}{r}-.2443 \\
(-51.50)\end{array}$ & & & \\
\hline IM91_95 & $\begin{array}{r}-.1626 \\
(-35.26)\end{array}$ & $\begin{array}{r}-.1639 \\
(-35.27)\end{array}$ & & & \\
\hline IM87_90 & $\begin{array}{r}-.0876 \\
(-18.99)\end{array}$ & $\begin{array}{r}-.0891 \\
(-19.23)\end{array}$ & $\begin{array}{r}-.1387 \\
(-51.87)\end{array}$ & $\begin{array}{r}-.1341 \\
(-49.77)\end{array}$ & \\
\hline IM85_86 & $\begin{array}{l}-.0347 \\
(-6.07)\end{array}$ & $\begin{array}{l}-.0345 \\
(-6.04)\end{array}$ & $\begin{array}{r}-.0698 \\
(-23.07)\end{array}$ & $\begin{array}{r}-.0693 \\
(-22.85)\end{array}$ & \\
\hline IM75_79 & $\begin{array}{r}.0544 \\
(11.07)\end{array}$ & $\begin{array}{r}.0546 \\
(11.06)\end{array}$ & $\begin{array}{r}.0796 \\
(33.12)\end{array}$ & $\begin{array}{r}.0789 \\
(32.64)\end{array}$ & $\begin{array}{r}-.0956 \\
(-19.20)\end{array}$ \\
\hline IM70_74 & $\begin{array}{r}.1069 \\
(19.64)\end{array}$ & $\begin{array}{r}.1073 \\
(19.68)\end{array}$ & $\begin{array}{r}.1312 \\
(50.16)\end{array}$ & $\begin{array}{r}.1316 \\
(50.21)\end{array}$ & * \\
\hline IM65_69 & $\begin{array}{r}.1222 \\
(19.04)\end{array}$ & $\begin{array}{r}.1222 \\
(19.02)\end{array}$ & $\begin{array}{r}.1690 \\
(58.01)\end{array}$ & $\begin{array}{r}.1695 \\
(58.13)\end{array}$ & $\begin{array}{r}.0574 \\
(11.18)\end{array}$ \\
\hline IM96_00*FSUJEW & & $\begin{array}{l}-.1580 \\
(-6.36)\end{array}$ & & & \\
\hline IM91_95*FSUJEW & & $\begin{array}{l}-.0147 \\
(-0.53)\end{array}$ & & & \\
\hline IM87_90*FSUJEW & & $\begin{array}{r}.03281 \\
(1.00)\end{array}$ & & $\begin{array}{r}-.2527 \\
(-10.31)\end{array}$ & \\
\hline IM85_86*FSUJEW & & $\begin{array}{l}.0036 \\
(0.04)\end{array}$ & & $\begin{array}{l}-.0456 \\
(-0.85)\end{array}$ & \\
\hline IM75_79*FSUJEW & & $\begin{array}{l}-.0386 \\
(-0.99)\end{array}$ & & $\begin{array}{l}-.0249 \\
(-1.00)\end{array}$ & \\
\hline IM70_74*FSUJEW & & $\begin{array}{l}-.0421 \\
(-0.58)\end{array}$ & & $\begin{array}{l}-.0346 \\
(-0.87)\end{array}$ & \\
\hline IM65_69*FSUJEW & & $\begin{array}{l}.0514 \\
(0.57)\end{array}$ & & $\begin{array}{l}.0263 \\
(0.45)\end{array}$ & \\
\hline MARRSP & $\begin{array}{r}.0397 \\
(12.98)\end{array}$ & $\begin{array}{r}.0399 \\
(13.05)\end{array}$ & $\begin{array}{r}.0404 \\
(20.53)\end{array}$ & $\begin{array}{r}.0409 \\
(20.78)\end{array}$ & $\begin{array}{l}.0134 \\
(2.17)\end{array}$ \\
\hline RURAL & $\begin{array}{l}.0188 \\
(1.58)\end{array}$ & $\begin{array}{l}.0189 \\
(1.59)\end{array}$ & $\begin{array}{l}.0177 \\
(4.55)\end{array}$ & $\begin{array}{l}.0177 \\
(4.55)\end{array}$ & $\begin{array}{l}.0102 \\
(1.16)\end{array}$ \\
\hline SOUTH & $\begin{array}{l}.0083 \\
(2.79)\end{array}$ & $\begin{array}{l}.0083 \\
(2.79)\end{array}$ & $\begin{array}{l}.0174 \\
(8.99)\end{array}$ & $\begin{array}{l}.0175 \\
(9.03)\end{array}$ & $\begin{array}{l}.0030 \\
(0.60)\end{array}$ \\
\hline CHILD & $\begin{array}{l}-.0149 \\
(-4.98)\end{array}$ & $\begin{array}{l}-.0147 \\
(-4.88)\end{array}$ & $\begin{array}{r}-.0267 \\
(-14.16)\end{array}$ & $\begin{array}{r}-0.260 \\
(-13.80)\end{array}$ & $\begin{array}{l}.0093 \\
(1.98)\end{array}$ \\
\hline FORMAR (a) & & & & & $\begin{array}{r}-.0431 \\
(8.32)\end{array}$ \\
\hline FSU & $\begin{array}{r}-.0979 \\
(-10.00)\end{array}$ & $\begin{array}{l}-.0492 \\
(-2.18)\end{array}$ & $\begin{array}{r}-.1374 \\
(-16.05)\end{array}$ & $\begin{array}{l}-.0273 \\
(-1.31)\end{array}$ & $\begin{array}{l}-.1384 \\
(-7.47)\end{array}$ \\
\hline ASIA & $\begin{array}{r}-.0739 \\
(-15.05)\end{array}$ & $\begin{array}{r}-.0754 \\
(-15.20)\end{array}$ & $\begin{array}{r}-.0632 \\
(-22.43)\end{array}$ & $\begin{array}{r}-.0631 \\
(-22.43)\end{array}$ & $\begin{array}{l}-.0431 \\
(-6.97)\end{array}$ \\
\hline
\end{tabular}




\begin{tabular}{|c|c|c|c|c|c|}
\hline LATAMER & $\begin{array}{r}-.1768 \\
(-36.33)\end{array}$ & $\begin{array}{r}-.1777 \\
(-36.38)\end{array}$ & $\begin{array}{r}-.1514 \\
(-54.87)\end{array}$ & $\begin{array}{r}-.1514 \\
(-54.88)\end{array}$ & $\begin{array}{r}-.1445 \\
(-25.13)\end{array}$ \\
\hline CANADA & $\begin{array}{l}.0825 \\
(7.73)\end{array}$ & $\begin{array}{l}.0812 \\
(7.60)\end{array}$ & $\begin{array}{r}.0739 \\
(11.05)\end{array}$ & $\begin{array}{r}.0739 \\
(11.06)\end{array}$ & $\begin{array}{l}.1265 \\
(9.26)\end{array}$ \\
\hline OTHER & $\begin{array}{l}.0621 \\
(7.91)\end{array}$ & $\begin{array}{l}.0601 \\
(7.73)\end{array}$ & $\begin{array}{l}-.0228 \\
(-6.10)\end{array}$ & $\begin{array}{l}-.0227 \\
(-6.08)\end{array}$ & $\begin{array}{l}.0202 \\
(2.41)\end{array}$ \\
\hline SAMPLE SIZE & 90383 & 90383 & 227554 & 227554 & 35915 \\
\hline STANDARD ERROR & .39307 & .3929 & .3879 & .3877 & .3790 \\
\hline $\mathbf{R} 2$ & .2711 & .2718 & .2649 & .2656 & .3047 \\
\hline ADJUSTED R2 & .2710 & .2716 & .2649 & .2655 & .3044 \\
\hline
\end{tabular}

t-ratios in parentheses.

(a) Variable cannot be reconstructed for 1990, 2000 Census.

${ }^{*}$ omitted as benchmark; benchmark is 1980-1984 and EUROPE unless otherwise noted.

Source: 2000 Census of Population, Public Use Microdata Sample, 5\% Sample.

1990 Census of Population, Public Use Microdata Sample, 5\% Sample.

1980 Census of Population, Public Use Sample, B and C Sample Files Combined, 2\% Sample. 
Table 7

Regression Analysis of Earnings Among Adult Males Who Immigrated Since 1965, 2000 Dependent Variable=LNEARN 2000 Census

\begin{tabular}{|c|c|c|c|c|c|c|c|c|}
\hline \multirow{2}{*}{$\begin{array}{c}\text { Immigration } \\
\text { Period: } \\
\text { Variable }\end{array}$} & \multicolumn{2}{|c|}{$1965-2000$} & \multicolumn{2}{|c|}{$1965-1979$} & \multicolumn{2}{|c|}{$1980-1989$} & \multicolumn{2}{|c|}{$1990-2000$} \\
\hline & (1) & (2) & (1) & (2) & (1) & (2) & (1) & (2) \\
\hline CONSTANT & $\begin{array}{r}\mathbf{6 . 2 4 8} \\
(451.41)\end{array}$ & $\begin{array}{r}\mathbf{6 . 2 4 8} \\
(451.29)\end{array}$ & $\begin{array}{r}\mathbf{6 . 0 3 0} \\
(214.00)\end{array}$ & $\begin{array}{r}\mathbf{6 . 0 3 0} \\
(213.99)\end{array}$ & $\begin{array}{r}\mathbf{6 . 5 8 1} \\
(28050)\end{array}$ & $\begin{array}{r}\mathbf{6 . 5 7 8} \\
(280.29)\end{array}$ & $\begin{array}{r}\mathbf{6 . 1 4 3} \\
(29194)\end{array}$ & $\begin{array}{r}\mathbf{6 . 1 4 2} \\
(291.77)\end{array}$ \\
\hline EDUCYRS & $\begin{array}{r}.0461 \\
(130.43)\end{array}$ & $\begin{array}{r}.0458 \\
(129.27)\end{array}$ & $\begin{array}{r}.0547 \\
(75.35)\end{array}$ & $\begin{array}{r}.0546 \\
(75.03)\end{array}$ & $\begin{array}{r}.0438 \\
(77.98)\end{array}$ & $\begin{array}{r}.0437 \\
(77.63)\end{array}$ & $\begin{array}{r}.0415 \\
(70.28)\end{array}$ & $\begin{array}{r}.0412 \\
(69.59)\end{array}$ \\
\hline EXP & $\begin{array}{r}.0108 \\
(22.35)\end{array}$ & $\begin{array}{r}.0108 \\
(22.40)\end{array}$ & $\begin{array}{r}.0113 \\
(11.34)\end{array}$ & $\begin{array}{r}.0113 \\
(11.37)\end{array}$ & $\begin{array}{r}.0127 \\
(14.85)\end{array}$ & $\begin{array}{r}.0127 \\
(14.84)\end{array}$ & $\begin{array}{r}.0084 \\
(10.62)\end{array}$ & $\begin{array}{r}.0084 \\
(10.50)\end{array}$ \\
\hline EXPSQ & $\begin{array}{l}-.00017 \\
(-19.61)\end{array}$ & $\begin{array}{l}-.00017 \\
(-19.78)\end{array}$ & $\begin{array}{r}-.00014 \\
(-8.20)\end{array}$ & $\begin{array}{r}-.00014 \\
(-8.26)\end{array}$ & $\begin{array}{l}-.00022 \\
(-14.06)\end{array}$ & $\begin{array}{l}-.00022 \\
(-14.09)\end{array}$ & $\begin{array}{l}-.00016 \\
(-10.21)\end{array}$ & $\begin{array}{l}-.00016 \\
(-10.19)\end{array}$ \\
\hline LNWW & $\begin{array}{r}.8461 \\
(314.94)\end{array}$ & $\begin{array}{r}-.8459 \\
(314.93)\end{array}$ & $\begin{array}{r}.8656 \\
(151.51)\end{array}$ & $\begin{array}{r}.8656 \\
(151.51)\end{array}$ & $\begin{array}{r}.7757 \\
(170.96)\end{array}$ & $\begin{array}{r}.7757 \\
(170.96)\end{array}$ & $\begin{array}{r}\mathbf{8 8 7 9} \\
(218.39)\end{array}$ & $\begin{array}{r}\mathbf{8 8 7 6} \\
(218.35)\end{array}$ \\
\hline IM95_00 & $\begin{array}{r}-.1554 \\
(-35.35)\end{array}$ & $\begin{array}{r}-.1503 \\
(-34.06)\end{array}$ & & & & & $\begin{array}{r}-.0530 \\
(-12.56)\end{array}$ & $\begin{array}{r}-.0483 \\
(-11.29)\end{array}$ \\
\hline IM90_94 & $\begin{array}{r}-.1041 \\
(-24.20)\end{array}$ & $\begin{array}{r}-.1027 \\
(-23.71)\end{array}$ & & & & & & \\
\hline IM85_89 & $\begin{array}{r}-.0434 \\
(-10.46)\end{array}$ & $\begin{array}{r}-.0434 \\
(-10.44)\end{array}$ & & & $\begin{array}{r}-.0459 \\
(-11.26)\end{array}$ & $\begin{array}{r}-.0457 \\
(-11.16)\end{array}$ & & \\
\hline IM75_79 & $\begin{array}{r}.0562 \\
(12.25)\end{array}$ & $\begin{array}{r}.0561 \\
(12.18)\end{array}$ & $\begin{array}{l}-.0388 \\
(-6.82)\end{array}$ & $\begin{array}{l}-.0392 \\
(-6.88)\end{array}$ & & & & \\
\hline IM70_74 & $\begin{array}{r}.0965 \\
(18.68)\end{array}$ & $\begin{array}{r}.0986 \\
(19.04)\end{array}$ & * & ( & & & & \\
\hline IM65_69 & $\begin{array}{r}.1184 \\
(19.18)\end{array}$ & $\begin{array}{r}-1214 \\
(19.64)\end{array}$ & $\begin{array}{l}.0270 \\
(3.87)\end{array}$ & $\begin{array}{l}.0277 \\
(3.96)\end{array}$ & & & & \\
\hline IM95_00*FSUJEW & & $\begin{array}{l}-.3447 \\
(-9.29)\end{array}$ & & & & & & $\begin{array}{l}-.1395 \\
(-5.85)\end{array}$ \\
\hline IM90_94*FSUJEW & & $\begin{array}{l}-.2299 \\
(-6.36)\end{array}$ & & & & & & \\
\hline IM85_89*FSUJEW & & $\begin{array}{l}-.1048 \\
(-2.49)\end{array}$ & & & & $\begin{array}{l}-.0306 \\
(-0.68)\end{array}$ & & \\
\hline IM75_79*FSUJEW & & $\begin{array}{l}-.1148 \\
(-2.61)\end{array}$ & & $\begin{array}{l}.0101 \\
(0.13)\end{array}$ & & & & \\
\hline IM70_74*FSUJEW & & $\begin{array}{l}-.2233 \\
(-2.80)\end{array}$ & & 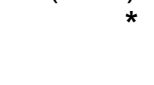 & & & & \\
\hline IM65_69*FSUJEW & & $\begin{array}{l}-.2416 \\
(-2.00)\end{array}$ & & $\begin{array}{l}-.1297 \\
(-0.94)\end{array}$ & & & & \\
\hline ENGSPK & $\begin{array}{r}.1742 \\
(54.05)\end{array}$ & $\begin{array}{r}.1738 \\
(53.92)\end{array}$ & $\begin{array}{r}.1371 \\
(18.18)\end{array}$ & $\begin{array}{r}.1373 \\
(18.21)\end{array}$ & $\begin{array}{r}.1643 \\
(32.43)\end{array}$ & $\begin{array}{r}.1645 \\
(32.48)\end{array}$ & $\begin{array}{r}.2018 \\
(40.27)\end{array}$ & $\begin{array}{r}.2007 \\
(40.04)\end{array}$ \\
\hline MARRSP & $\begin{array}{r}.2115 \\
(78.13)\end{array}$ & $\begin{array}{r}.2121 \\
(78.35)\end{array}$ & $\begin{array}{r}.2661 \\
(47.16)\end{array}$ & $\begin{array}{r}.2659 \\
(47.14)\end{array}$ & $\begin{array}{r}.2168 \\
(49.57)\end{array}$ & $\begin{array}{r}.2168 \\
(49.58)\end{array}$ & $\begin{array}{r}.1699 \\
(38.95)\end{array}$ & $\begin{array}{r}.1707 \\
(39.13)\end{array}$ \\
\hline RURAL & $\begin{array}{l}-.0804 \\
(-7.10)\end{array}$ & $\begin{array}{l}-.0807 \\
(-7.12)\end{array}$ & $\begin{array}{l}-.1349 \\
(-5.64)\end{array}$ & $\begin{array}{l}-.1348 \\
(-5.64)\end{array}$ & $\begin{array}{l}-.0536 \\
(-2.91)\end{array}$ & $\begin{array}{l}-.0536 \\
(-2.91)\end{array}$ & $\begin{array}{l}-.0740 \\
(-4.16)\end{array}$ & $\begin{array}{l}-0741 \\
(-4.17)\end{array}$ \\
\hline SOUTH & $\begin{array}{r}-.0288 \\
(-10.25)\end{array}$ & $\begin{array}{r}-.0292 \\
(-10.37)\end{array}$ & $\begin{array}{l}-.0551 \\
(-9.67)\end{array}$ & $\begin{array}{l}-.0552 \\
(-9.68)\end{array}$ & $\begin{array}{l}-.0230 \\
(-5.02)\end{array}$ & $\begin{array}{l}-.0231 \\
(-5.03)\end{array}$ & $\begin{array}{l}-.0158 \\
(-3.49)\end{array}$ & $\begin{array}{l}-.0162 \\
(-3.58)\end{array}$ \\
\hline FSU & $\begin{array}{r}-.1850 \\
(-19.46)\end{array}$ & $\begin{array}{r}-.3106 \\
(-15.30)\end{array}$ & $\begin{array}{l}-.0309 \\
(-1.17)\end{array}$ & $\begin{array}{l}-.1983 \\
(-3.17)\end{array}$ & $\begin{array}{l}-.1178 \\
(-5.76)\end{array}$ & $\begin{array}{l}-.3136 \\
(-7.36)\end{array}$ & $\begin{array}{r}-.2545 \\
(-21.26)\end{array}$ & $\begin{array}{r}-.3448 \\
(-14.39)\end{array}$ \\
\hline ASIA & $\begin{array}{r}-.1673 \\
(-36.48)\end{array}$ & $\begin{array}{r}-.1608 \\
(-34.46)\end{array}$ & $\begin{array}{l}-.0521 \\
(-6.23)\end{array}$ & $\begin{array}{l}-.0492 \\
(-5.84)\end{array}$ & $\begin{array}{r}-.2302 \\
(-27.39)\end{array}$ & $\begin{array}{r}-.2232 \\
(-26.24)\end{array}$ & $\begin{array}{r}-.2280 \\
(-30.89)\end{array}$ & $\begin{array}{r}-.2198 \\
(-28.93)\end{array}$ \\
\hline LATAMER & $\begin{array}{r}-.3247 \\
(-70.91)\end{array}$ & $\begin{array}{r}-.3211 \\
(-69.62)\end{array}$ & $\begin{array}{r}-.2137 \\
(-26.89)\end{array}$ & $\begin{array}{r}-.2122 \\
(-26.65)\end{array}$ & $\begin{array}{r}-.3838 \\
(-45.74)\end{array}$ & $\begin{array}{r}-.3789 \\
(-44.86)\end{array}$ & $\begin{array}{r}-.3927 \\
(-51.24)\end{array}$ & $\begin{array}{r}-.3881 \\
(-50.10)\end{array}$ \\
\hline
\end{tabular}




\begin{tabular}{|c|c|c|c|c|c|c|c|c|}
\hline CANADA & $\begin{array}{r}.1327 \\
(-13.09)\end{array}$ & $\begin{array}{l}-.1371 \\
(13.50)\end{array}$ & $\begin{array}{l}.0316 \\
(1.76)\end{array}$ & $\begin{array}{l}.0333 \\
(1.85)\end{array}$ & $\begin{array}{l}.1309 \\
(6.31)\end{array}$ & $\begin{array}{l}.1366 \\
(6.57)\end{array}$ & $\begin{array}{r}.2070 \\
(13.47)\end{array}$ & $\begin{array}{r}.2131 \\
(13.82)\end{array}$ \\
\hline OTHER & $\begin{array}{r}-.2071 \\
(-27.88)\end{array}$ & $\begin{array}{r}-.2025 \\
(-27.16)\end{array}$ & $\begin{array}{l}-.0870 \\
(-5.62)\end{array}$ & $\begin{array}{l}-.0849 \\
(-5.47)\end{array}$ & $\begin{array}{r}-.2181 \\
(-16.73)\end{array}$ & $\begin{array}{r}.2125 \\
(16.25)\end{array}$ & $\begin{array}{r}-.3113 \\
(-27.26)\end{array}$ & $\begin{array}{r}-.3054 \\
(-26.93)\end{array}$ \\
\hline FSU*EDUCYRS & & $\begin{array}{r}.0244 \\
(11.02)\end{array}$ & & $\begin{array}{l}.0129 \\
(2.29)\end{array}$ & & $\begin{array}{l}.0174 \\
(5.01)\end{array}$ & & $\begin{array}{l}.0112 \\
(6.31)\end{array}$ \\
\hline $\begin{array}{r}\text { SAMPLE SIZE } \\
\text { STANDARD } \\
\text { ERROR }\end{array}$ & $\begin{array}{r}398520 \\
.7833\end{array}$ & $\begin{array}{r}398520 \\
.7831\end{array}$ & $\begin{array}{r}110840 \\
.8121\end{array}$ & $\begin{array}{r}110840 \\
.8120\end{array}$ & $\begin{array}{r}145315 \\
.7621\end{array}$ & $\begin{array}{r}145315 \\
.7769\end{array}$ & $\begin{array}{r}142363 \\
.7774\end{array}$ & $\begin{array}{r}142363 \\
.7772\end{array}$ \\
\hline $\begin{array}{r}\text { R2 } \\
\text { ADJUSTED R2 } \\
\end{array}$ & $\begin{array}{l}.3580 \\
.3580 \\
\end{array}$ & $\begin{array}{l}.3583 \\
.3583 \\
\end{array}$ & $\begin{array}{l}.3225 \\
.3224\end{array}$ & $\begin{array}{l}.3226 \\
.3225 \\
\end{array}$ & $\begin{array}{l}.3176 \\
.3175 \\
\end{array}$ & $\begin{array}{l}.3217 \\
.3213\end{array}$ & $\begin{array}{l}.3886 \\
.3885 \\
\end{array}$ & $\begin{array}{l}.3888 \\
.3887 \\
\end{array}$ \\
\hline
\end{tabular}

t-ratios in parentheses.

Includes only immigrants who worked and had non-zero earnings in 1999.

*omitted as benchmark; benchmark is 1980-1984 and EUROPE unless otherwise noted.

Source: 2000 Census of Population, Public Use Microdata Sample, 5\% Sample 1990 Census of Population, Public Use Microdata Sample, 5\% Sample

1980 Census of Population, Public Use Sample, B and C Sample Files Combined, 2\% Sample 
Table 8

Regression Analysis of Earnings Among Adult Males Who Immigrated Since 1965: 2000, 1990, 1980

Dependent Variable=LNEARN

\begin{tabular}{|c|c|c|c|c|c|}
\hline & \multicolumn{2}{|c|}{2000 Census } & \multicolumn{2}{|c|}{1990 Census } & \multirow{2}{*}{$\begin{array}{l}1980 \text { Census } \\
1980-1989 \\
(1)\end{array}$} \\
\hline $\begin{array}{l}\text { Immigration Period: } \\
\text { Variable }\end{array}$ & $\begin{array}{l}196 \\
(1)\end{array}$ & $\begin{array}{r}2000 \\
(2) \\
\end{array}$ & $\begin{array}{c}196 \\
(1)\end{array}$ & 1979 (2) & \\
\hline CONSTANT & $\begin{array}{r}6.198 \\
(200.12)\end{array}$ & $\begin{array}{r}6.201 \\
(200.29)\end{array}$ & $\begin{array}{r}5.204 \\
(303.00)\end{array}$ & $\begin{array}{r}5.208 \\
(303.01)\end{array}$ & $\begin{array}{r}4.360 \\
(102.18)\end{array}$ \\
\hline EDUCYRS & $\begin{array}{l}.04507 \\
(57.14)\end{array}$ & $\begin{array}{r}.0447 \\
(56.49)\end{array}$ & $\begin{array}{r}.0480 \\
(103.10)\end{array}$ & $\begin{array}{r}.0479 \\
(102.62)\end{array}$ & $\begin{array}{r}.0462 \\
(40.89)\end{array}$ \\
\hline EXP & $\begin{array}{l}.0102 \\
(9.40)\end{array}$ & $\begin{array}{l}.0103 \\
(9.43)\end{array}$ & $\begin{array}{r}.0268 \\
(42.81)\end{array}$ & $\begin{array}{r}.0267 \\
(42.71)\end{array}$ & $\begin{array}{r}.0300 \\
(19.77)\end{array}$ \\
\hline EXPSQ & $\begin{array}{l}-.0002 \\
(-8.72)\end{array}$ & $\begin{array}{l}-.0002 \\
(-8.83)\end{array}$ & $\begin{array}{r}-.0004 \\
(-34.33)\end{array}$ & $\begin{array}{r}-.0004 \\
(-34.26)\end{array}$ & $\begin{array}{r}-.0005 \\
(-16.88)\end{array}$ \\
\hline LNWW & $\begin{array}{r}.8679 \\
(145.45)\end{array}$ & $\begin{array}{r}.8675 \\
(145.44)\end{array}$ & $\begin{array}{r}.9534 \\
(270.03)\end{array}$ & $\begin{array}{r}.9526 \\
(269.66)\end{array}$ & $\begin{array}{r}1.048 \\
(114.66)\end{array}$ \\
\hline IM96_00 & $\begin{array}{r}-.1598 \\
(-15.34)\end{array}$ & $\begin{array}{r}-.1501 \\
(-14.37)\end{array}$ & & & \\
\hline IM91_95 & $\begin{array}{r}-.1229 \\
(-12.53)\end{array}$ & $\begin{array}{r}-.1205 \\
(-12.19)\end{array}$ & & & \\
\hline IM87_90 & $\begin{array}{l}-.0692 \\
(-7.13)\end{array}$ & $\begin{array}{l}-.0705 \\
(-7.23)\end{array}$ & $\begin{array}{r}-.0949 \\
(-16.32)\end{array}$ & $\begin{array}{r}-.0910 \\
(-15.57)\end{array}$ & \\
\hline IM85_86 & $\begin{array}{l}-.0448 \\
(-3.75)\end{array}$ & $\begin{array}{l}-.0429 \\
(-3.59)\end{array}$ & $\begin{array}{r}-.0708 \\
(-11.46)\end{array}$ & $\begin{array}{r}-.0698 \\
(-11.28)\end{array}$ & \\
\hline IM75_79 & $\begin{array}{l}.0561 \\
(5.42)\end{array}$ & $\begin{array}{r}.0557 \\
(5.360\end{array}$ & $\begin{array}{r}.1062 \\
(21.85)\end{array}$ & $\begin{array}{r}.1069 \\
(21.90)\end{array}$ & $\begin{array}{r}-.1345 \\
(-13.12)\end{array}$ \\
\hline IM70_74 & $\begin{array}{l}.0913 \\
(7.92)\end{array}$ & $\begin{array}{l}.0931 \\
(8.06)\end{array}$ & $\begin{array}{r}.1787 \\
(33.67)\end{array}$ & $\begin{array}{r}.1797 \\
(33.78)\end{array}$ & * \\
\hline IM65_69 & $\begin{array}{l}.1124 \\
(8.17)\end{array}$ & $\begin{array}{l}.1152 \\
(8.36)\end{array}$ & $\begin{array}{r}.1996 \\
(33.64)\end{array}$ & $\begin{array}{r}.2006 \\
(33.76)\end{array}$ & $\begin{array}{l}.0804 \\
(7.60)\end{array}$ \\
\hline IM96_00*FSUJEW & $\begin{array}{l}-.5036 \\
(-6.39)\end{array}$ & & & & \\
\hline IM91_95*FSUJEW & $\begin{array}{l}-.3033 \\
(-3.97)\end{array}$ & & & & \\
\hline IM87_90*FSUJEW & $\begin{array}{l}-.1352 \\
(-1.60)\end{array}$ & & $\begin{array}{l}-.3090 \\
(-5.65)\end{array}$ & & \\
\hline IM85_86*FSUJEW & $\begin{array}{l}-.3156 \\
(-1.73)\end{array}$ & & $\begin{array}{l}-.1979 \\
(-1.79)\end{array}$ & & \\
\hline IM75_79*FSUJEW & $\begin{array}{l}-.0911 \\
(-0.95)\end{array}$ & & $\begin{array}{l}-.1458 \\
(-2.85)\end{array}$ & & \\
\hline IM70_74*FSUJEW & $\begin{array}{l}-.0100 \\
(-0.06)\end{array}$ & & $\begin{array}{l}-.1137 \\
(-1.40)\end{array}$ & & \\
\hline IM65_69*FSUJEW & $\begin{array}{l}-.1193 \\
(-0.56)\end{array}$ & & $\begin{array}{l}.0029 \\
(0.02)\end{array}$ & & \\
\hline ENGSPK & $\begin{array}{r}.1755 \\
(24.40)\end{array}$ & $\begin{array}{r}.1743 \\
(24.24)\end{array}$ & $\begin{array}{r}.1723 \\
(39.38)\end{array}$ & $\begin{array}{r}.1717 \\
(39.25)\end{array}$ & $\begin{array}{r}.1632 \\
(14.84)\end{array}$ \\
\hline MARRSP & $\begin{array}{r}.2022 \\
(33.38)\end{array}$ & $\begin{array}{r}.2030 \\
(33.52)\end{array}$ & $\begin{array}{r}.2093 \\
(57.12)\end{array}$ & $\begin{array}{r}.2099 \\
(57.26)\end{array}$ & $\begin{array}{r}.1718 \\
(16.11)\end{array}$ \\
\hline RURAL & $\begin{array}{l}-.1159 \\
(-4.51)\end{array}$ & $\begin{array}{l}-.1163 \\
(-4.53)\end{array}$ & $\begin{array}{l}-.0183 \\
(-2.36)\end{array}$ & $\begin{array}{l}-.0186 \\
(-2.40)\end{array}$ & $\begin{array}{l}-0190 \\
(-1.03)\end{array}$ \\
\hline SOUTH & $\begin{array}{l}-.0386 \\
(-6.13)\end{array}$ & $\begin{array}{l}-.0389 \\
(-6.19)\end{array}$ & $\begin{array}{r}-.0925 \\
(-23.52)\end{array}$ & $\begin{array}{r}-.0925 \\
(-23.51)\end{array}$ & $\begin{array}{l}-.0312 \\
(-2.97)\end{array}$ \\
\hline FSU & $\begin{array}{l}-.1937 \\
(-9.11)\end{array}$ & $\begin{array}{l}-.2899 \\
(-5.11)\end{array}$ & $\begin{array}{l}-.1759 \\
(-9.36)\end{array}$ & $\begin{array}{l}-.3021 \\
(-3.42)\end{array}$ & $\begin{array}{r}.0895 \\
(-0.66)\end{array}$ \\
\hline
\end{tabular}




\begin{tabular}{|c|c|c|c|c|c|}
\hline ASIA & $\begin{array}{r}-.1592 \\
(-15.35)\end{array}$ & $\begin{array}{r}-.1559 \\
(-14.89)\end{array}$ & $\begin{array}{r}-.1955 \\
(-34.34)\end{array}$ & $\begin{array}{r}-.1953 \\
(-34.32)\end{array}$ & $\begin{array}{r}-.1862 \\
(-14.44)\end{array}$ \\
\hline LATAMER & $\begin{array}{r}-.3224 \\
(-31.39)\end{array}$ & $\begin{array}{r}-.3216 \\
(-31.20)\end{array}$ & $\begin{array}{r}-.3227 \\
(-57.83)\end{array}$ & $\begin{array}{r}-.3231 \\
(-57.90)\end{array}$ & $\begin{array}{r}-.2612 \\
(-21.63)\end{array}$ \\
\hline CANADA & $\begin{array}{l}.1760 \\
(7.92)\end{array}$ & $\begin{array}{l}.1777 \\
(8.00)\end{array}$ & $\begin{array}{l}.0936 \\
(6.99)\end{array}$ & $\begin{array}{l}.0937 \\
(7.00)\end{array}$ & $\begin{array}{l}.1375 \\
(4.83)\end{array}$ \\
\hline OTHER & $\begin{array}{r}-.2180 \\
(-13.14)\end{array}$ & $\begin{array}{r}-.2159 \\
(-12.99)\end{array}$ & $\begin{array}{r}-.2511 \\
(-32.60)\end{array}$ & $\begin{array}{r}-.2511 \\
(-32.60)\end{array}$ & $\begin{array}{r}-.2276 \\
(-13.03)\end{array}$ \\
\hline FSU*EDUCYRS & & $\begin{array}{l}.0256 \\
(5.41)\end{array}$ & & $\begin{array}{l}.0194 \\
(3.79)\end{array}$ & $\begin{array}{l}-.0280 \\
(-3.08)\end{array}$ \\
\hline SAMPLE SIZE & 79582 & 79582 & 202113 & 202113 & 35915 \\
\hline STANDARD ERROR & .7830 & .7827 & .7456 & .7455 & .7898 \\
\hline R2 & .3646 & .3652 & .4267 & .4268 & .3895 \\
\hline ADJUSTED R2 & .3645 & .3650 & .4266 & .4268 & .3892 \\
\hline
\end{tabular}

t-ratios in parentheses.

*omitted as benchmark; 1980-1984 and EUROPE are benchmarks unless otherwise noted.

Source: 2000 Census of Population, Public Use Microdata Sample, 5\% Sample 1990 Census of Population, Public Use Microdata Sample, 5\% Sample

1980 Census of Population, Public Use Sample, B and C Sample Files Combined, 2\% Sample. 
Appendix Table A-1

\section{Ancestry or Ethnic Origin of Adult Male Soviet Immigrants Who Immigrated Since 1965, 2000 (percent)}

\begin{tabular}{|c|c|c|c|c|c|c|c|c|}
\hline \multirow{3}{*}{$\begin{array}{l}\text { Ethnic } \\
\text { Ancestry }\end{array}$} & \multicolumn{8}{|c|}{ Period of Immigration } \\
\hline & \multicolumn{2}{|c|}{$1965-2000$} & \multicolumn{2}{|c|}{$1965-1979$} & \multicolumn{2}{|c|}{ 1980-1989 } & \multicolumn{2}{|c|}{$1990-2000$} \\
\hline & All & $\begin{array}{c}\text { Excl. } \\
\text { Armenian/ } \\
\text { Ukrainian (a) }\end{array}$ & All & $\begin{array}{c}\text { Excl. } \\
\text { Armenian/ } \\
\text { Ukrainian }^{\text {(a) }}\end{array}$ & All & $\begin{array}{c}\text { Excl. } \\
\text { Armenian/ } \\
\text { Ukrainian }^{(a)}\end{array}$ & All & $\begin{array}{c}\text { Excl. } \\
\text { Armenian/ }^{\text {Ukrainian }}{ }^{(a)}\end{array}$ \\
\hline Russian & 41.1 & 52.6 & 36.7 & 49.9 & 39.1 & 51.9 & 41.4 & 53.2 \\
\hline Religion ${ }^{(b)}$ & 9.6 & 11.7 & 10.9 & 10.3 & 9.6 & 13.7 & 9.7 & 11.5 \\
\hline Armenian & 10.8 & -- & 12.7 & -- & 17.1 & -- & 9.8 & -- \\
\hline Ukrainian & 19.9 & 18.1 & 18.9 & 19.8 & 18.3 & 14.9 & 20.9 & 18.5 \\
\hline Not Reported & 5.8 & 5.6 & 6.7 & 8.4 & 7.3 & 6.9 & 5.4 & 4.8 \\
\hline Soviet Union, n.e.c. ${ }^{(c)}$ & 4.7 & 2.6 & 1.3 & 0.4 & 1.1 & 2.3 & 5.4 & 3.1 \\
\hline Lithuanian & 1.5 & 1.5 & 0.8 & 1.1 & 1.3 & 1.8 & 1.5 & 1.5 \\
\hline Latvian & 0.8 & 0.8 & 1.6 & 1.1 & 1.5 & 1.0 & 0.5 & 0.7 \\
\hline Polish & 0.3 & 0.5 & 1.3 & 1.3 & 0.0 & 0.7 & 0.1 & 0.2 \\
\hline All Other & $\underline{5.5}$ & $\underline{6.7}$ & $\underline{9.1}$ & 7.5 & $\underline{4.7}$ & $\underline{6.7}$ & $\underline{5.3}$ & $\underline{6.5}$ \\
\hline Total & 100.0 & 100.0 & 100.0 & 100.0 & 100.0 & 100.0 & 100.0 & 100.0 \\
\hline
\end{tabular}

Note: Detail may not add to total due to rounding.

${ }^{(a)}$ Excludes persons of Armenian ancestry or who speak Armenian or Ukrainian at home.

${ }^{(b)}$ Response to ancestry question indicating the person's religion or religious origin, ancestry code 998.

(c)Includes Azerbaijani, Belorussian, Estonian, Ossetian, Moldavian, Tatar, Turkestani, Uzbek, Georgian, Tajik and those who reported Soviet Union.

Source: 2000 Census of Population, Public Use Microdata Sample, 5 percent sample. 
Appendix Table A-2

Language Spoken in the Home by Adult Males Who Immigrated from the Former Soviet Union Since 1965, $2000^{(a)}$ (percent)

\begin{tabular}{lcccc}
\hline & \multicolumn{4}{c}{ Period of Immigration } \\
Language & $1965-2000$ & $1965-1979$ & $1980-1989$ & $1990-2000$ \\
\hline English only & 4.0 & 9.2 & 5.0 & 3.1 \\
Russian & 71.6 & 63.3 & 69.4 & 73.4 \\
Armenian & 9.4 & 12.7 & 17.3 & 8.0 \\
Ukrainian & 7.2 & 2.5 & 2.5 & 8.4 \\
Yiddish & 0.2 & 0.4 & 0.0 & 0.1 \\
Other & $\underline{7.6}$ & $\underline{11.9}$ & $\underline{5.8}$ & $\underline{7}$ \\
Total & 100.0 & 100.0 & 100.0 & 100.0 \\
\hline
\end{tabular}

Note: Detail may not add to total due to rounding.

(a) Language currently spoken in the home other than or in addition to English.

Source: 2000 Census of Population, Public Use Microdata Sample, 5 percent sample. 


\section{Appendix Table A-3}

Republic of Birth of Immigrants from the Former Soviet Union, Adult Males, by Period of Immigration Who Immigrated Since 1965, 2000.

\begin{tabular}{|c|c|c|c|c|c|c|c|c|}
\hline $\begin{array}{l}\text { Republic of } \\
\text { Birth }\end{array}$ & $1965-2000$ & & $1965-1979$ & & 1980-1989 & & $1990-2000$ & \\
\hline & $\begin{array}{r}\text { Non-Armenian/ } \\
\text { Ukrainian }^{(a)}\end{array}$ & All & $\begin{array}{r}\text { Non-Armenian/ } \\
\text { Ukrainian }^{(a)}\end{array}$ & All & $\begin{array}{r}\text { Non-Armenian/ } \\
\text { Ukrainian }^{(a)}\end{array}$ & All & $\begin{array}{r}\text { Non-Armenian/ } \\
\text { Ukrainian" }^{\text {(a) }}\end{array}$ & All \\
\hline Estonia & 4 & $\overline{4}$ & 2 & $\overline{2}$ & 1 & $\overline{1}$ & 1 & 1 \\
\hline Latvia & 120 & 120 & 24 & 24 & 40 & 40 & 56 & 56 \\
\hline Lithuania & 155 & 155 & 18 & 18 & 35 & 35 & 102 & 102 \\
\hline Armenia & 17 & 919 & 3 & 133 & 8 & 298 & 6 & 488 \\
\hline Azerbaijan & 114 & 168 & 7 & 7 & 15 & 16 & 92 & 145 \\
\hline Belarus & 417 & 421 & 15 & 15 & 87 & 87 & 315 & 319 \\
\hline Georgia & 106 & 121 & 7 & 8 & 14 & 15 & 85 & 98 \\
\hline Moldova & 228 & 236 & 25 & 25 & 24 & 24 & 179 & 187 \\
\hline Russia & 3540 & 3610 & 428 & 434 & 636 & 647 & 2476 & 2529 \\
\hline Ukraine & 2180 & 2848 & 319 & 344 & 361 & 425 & 1500 & 2079 \\
\hline USSR $^{(\mathrm{b})}$ & 454 & 488 & 100 & 102 & 115 & 121 & 239 & 265 \\
\hline Kazakhstan & 22 & 23 & 0 & 0 & 2 & 3 & 20 & 20 \\
\hline Kyrgyzstan & 5 & 5 & 0 & 0 & 0 & 0 & 5 & 5 \\
\hline Tajikstan & 8 & 8 & 0 & 0 & 3 & 3 & 5 & 5 \\
\hline Turkmenistan & 1 & 2 & 0 & 0 & 0 & 0 & 1 & 2 \\
\hline Uzbekistan & 250 & 256 & 15 & 15 & 26 & 26 & 209 & 215 \\
\hline Total & 7621 & 9384 & 963 & 1127 & 1367 & 1741 & 5291 & 6516 \\
\hline
\end{tabular}

(a) Excludes persons reporting Armenian ancestry, or who speak Armenian or Ukrainian at home.

(b) Persons reporting USSR rather than a specific republic.

Source: 2000 US Census of Population, Public Use Microdata Sample, 5 percent sample 


\section{Appendix Table A-4}

Period of Immigration for All Adult Male Immigrants

Born in the Former Soviet Union, Including Armenians, 2000. (percent)

\begin{tabular}{ccc}
\hline Period of Immigration & All Years & Since 1965 \\
\cline { 2 - 3 } $1995-1000$ & 37.4 & \\
$1990-1994$ & 26.3 & 38.7 \\
$1985-1989$ & 12.7 & 27.4 \\
$1980-1984$ & 8.2 & 13.2 \\
$1975-1979$ & 6.1 & 8.6 \\
$1970-1974$ & 2.7 & 6.4 \\
$1965-1969$ & 2.1 & 2.8 \\
$1960-1964$ & 1.9 & 2.2 \\
$1950-1959$ & 1.5 & -- \\
Before 1950 & $\underline{0.9}$ & -- \\
Total & 100.0 & 100.0 \\
\hline
\end{tabular}

Note: Detail may not add to total due to rounding.

Source: 2000 Census of Population, Public Use Microdata Sample, 5 percent sample. 
Appendix Table A-5

Regression Analysis of Fluency In English Among Adult Soviet Jewish Males

Who Immigrated Since 1965

Dependent Variable $=$ ENGSPK 2000 Census

\begin{tabular}{|c|c|c|c|c|c|c|c|c|}
\hline \multirow{2}{*}{$\begin{array}{c}\text { Immigration } \\
\text { Period: } \\
\text { Variable } \\
\end{array}$} & \multicolumn{2}{|c|}{$1965-2000$} & \multicolumn{2}{|c|}{$1965-1979$} & \multicolumn{2}{|c|}{ 1980-1989 } & \multicolumn{2}{|c|}{$1990-2000$} \\
\hline & (1) & (2) & (1) & (2) & (1) & (2) & (1) & (2) \\
\hline CONSTANT & $\begin{array}{r}.7773 \\
(22.19)\end{array}$ & $\begin{array}{r}.7793 \\
(21.83)\end{array}$ & $\begin{array}{r}.7989 \\
(13.55)\end{array}$ & $\begin{array}{r}.7897 \\
(13.12)\end{array}$ & $\begin{array}{r}.8356 \\
(14.06)\end{array}$ & $\begin{array}{r}.8364 \\
(13.76)\end{array}$ & $\begin{array}{r}.6814 \\
(17.25)\end{array}$ & $\begin{array}{r}.6921 \\
(17.07)\end{array}$ \\
\hline EDUCYRS & $\begin{array}{r}.0391 \\
(26.09)\end{array}$ & $\begin{array}{r}.0388 \\
(25.57)\end{array}$ & $\begin{array}{l}.0172 \\
(6.05)\end{array}$ & $\begin{array}{l}.0173 \\
(6.06)\end{array}$ & $\begin{array}{l}.0285 \\
(9.50)\end{array}$ & $\begin{array}{l}.0282 \\
(9.25)\end{array}$ & $\begin{array}{r}.0452 \\
(23.39)\end{array}$ & $\begin{array}{r}.0446 \\
(22.81)\end{array}$ \\
\hline AGE & $\begin{array}{r}-.0104 \\
(-22.69)\end{array}$ & $\begin{array}{r}-.0104 \\
(-22.74)\end{array}$ & $\begin{array}{l}-.0027 \\
(-3.52)\end{array}$ & $\begin{array}{l}-.0027 \\
(-3.57)\end{array}$ & $\begin{array}{l}-.0081 \\
(-9.27)\end{array}$ & $\begin{array}{l}-.0081 \\
(-9.32)\end{array}$ & $\begin{array}{r}-.0129 \\
(-21.03)\end{array}$ & $\begin{array}{r}-.0129 \\
(-21.08)\end{array}$ \\
\hline IM95_00 & $\begin{array}{r}-.3547 \\
(-18.16)\end{array}$ & $\begin{array}{r}-.3515 \\
(-17.97)\end{array}$ & & & & & $\begin{array}{r}-.2552 \\
(-21.93)\end{array}$ & $\begin{array}{r}-.2544 \\
(-21.83)\end{array}$ \\
\hline IM90_94 & $\begin{array}{l}-.1057 \\
(-5.62)\end{array}$ & $\begin{array}{l}-.1031 \\
(-5.47)\end{array}$ & & & & & & \\
\hline IM85_89 & $\begin{array}{l}-.0408 \\
(-1.93)\end{array}$ & $\begin{array}{l}-.0388 \\
(-1.83)\end{array}$ & & & $\begin{array}{l}-.0378 \\
(-2.15)\end{array}$ & $\begin{array}{l}-.0373 \\
(-2.11)\end{array}$ & & \\
\hline IM75_79 & $\begin{array}{l}.0386 \\
(1.77)\end{array}$ & $\begin{array}{l}.0428 \\
(1.96)\end{array}$ & $\begin{array}{l}.0051 \\
(0.22)\end{array}$ & $\begin{array}{r}-.0081 \\
(0.35)\end{array}$ & & & & \\
\hline IM70_74 & $\begin{array}{l}.0662 \\
(1.81)\end{array}$ & $\begin{array}{l}.0678 \\
(1.85)\end{array}$ & & & & & & \\
\hline IM65_69 & $\begin{array}{l}.1089 \\
(2.01)\end{array}$ & $\begin{array}{l}.1063 \\
(1.95)\end{array}$ & $\begin{array}{l}.0033 \\
(0.08)\end{array}$ & $\begin{array}{l}-.0021 \\
(-0.05)\end{array}$ & & & & \\
\hline MARRSP & $\begin{array}{l}.0123 \\
(1.08)\end{array}$ & $\begin{array}{l}.0128 \\
(1.12)\end{array}$ & $\begin{array}{c}-.0078 \\
(-0.39)\end{array}$ & $\begin{array}{l}-.0063 \\
(-0.31)\end{array}$ & $\begin{array}{l}.0141 \\
(0.65)\end{array}$ & $\begin{array}{l}.0142 \\
(0.66)\end{array}$ & $\begin{array}{l}.0161 \\
(1.06)\end{array}$ & $\begin{array}{l}.0160 \\
(1.06)\end{array}$ \\
\hline RURAL & $\begin{array}{l}.0247 \\
(0.38)\end{array}$ & $\begin{array}{l}.0255 \\
(0.39)\end{array}$ & $\begin{array}{l}.1399 \\
(0.87)\end{array}$ & $\begin{array}{r}.1328 \\
(0 . .83)\end{array}$ & $\begin{array}{l}-.0421 \\
(-0.33)\end{array}$ & $\begin{array}{l}-.0395 \\
(-0.31)\end{array}$ & $\begin{array}{l}.0126 \\
(0.15)\end{array}$ & $\begin{array}{l}.0136 \\
(0.17)\end{array}$ \\
\hline SOUTH & $\begin{array}{l}.0186 \\
(1.40)\end{array}$ & $\begin{array}{l}.0187 \\
(1.40)\end{array}$ & $\begin{array}{l}-.0021 \\
(-0.08)\end{array}$ & $\begin{array}{l}-.0025 \\
(-0.10)\end{array}$ & $\begin{array}{l}.0210 \\
(0.73)\end{array}$ & $\begin{array}{l}.0218 \\
(0.75)\end{array}$ & $\begin{array}{l}.0198 \\
(1.17)\end{array}$ & $\begin{array}{l}.0197 \\
(1.16)\end{array}$ \\
\hline CHILD & $\begin{array}{l}-.0074 \\
(-0.77)\end{array}$ & $\begin{array}{l}-.0070 \\
(-0.72)\end{array}$ & $\begin{array}{l}.0252 \\
(1.44)\end{array}$ & $\begin{array}{l}.0252 \\
(1.44)\end{array}$ & $\begin{array}{l}-.0108 \\
(-0.59)\end{array}$ & $\begin{array}{l}-.0110 \\
(-0.60)\end{array}$ & $\begin{array}{l}-.0085 \\
(-0.66)\end{array}$ & $\begin{array}{l}-.0075 \\
(-0.58)\end{array}$ \\
\hline UKRAINE & & $\begin{array}{l}-.0198 \\
(-1.68)\end{array}$ & & $\begin{array}{l}.0047 \\
(0.23)\end{array}$ & & $\begin{array}{l}.0053 \\
(0.22)\end{array}$ & & $\begin{array}{l}-.0315 \\
(-2.04)\end{array}$ \\
\hline RELIG & & $\begin{array}{l}.0245 \\
(1.75)\end{array}$ & & $\begin{array}{l}.0121 \\
(0.45)\end{array}$ & & $\begin{array}{l}.0312 \\
(1.29)\end{array}$ & & $\begin{array}{l}.0258 \\
(1.37)\end{array}$ \\
\hline OTHANCS & & $\begin{array}{l}.0081 \\
(0.67)\end{array}$ & & $\begin{array}{l}.0197 \\
(0.90)\end{array}$ & & $\begin{array}{l}.0061 \\
(0.28)\end{array}$ & & $\begin{array}{l}.0041 \\
(0.25)\end{array}$ \\
\hline SAMPLE SIZE & 6492 & 6492 & 856 & 856 & 1240 & 1240 & 4394 & 4394 \\
\hline $\begin{array}{r}\text { STANDARD } \\
\text { ERROR }\end{array}$ & .3440 & .3438 & .2235 & .2238 & .2833 & .2835 & .3733 & .3731 \\
\hline $\begin{array}{r}\mathrm{R} 2 \\
\text { ADJUSTED R2 } \\
\end{array}$ & $\begin{array}{l}.2347 \\
.2333\end{array}$ & $\begin{array}{l}.2356 \\
.2338\end{array}$ & $\begin{array}{l}.0651 \\
.0563\end{array}$ & $\begin{array}{l}.0661 \\
.0539\end{array}$ & $\begin{array}{l}.1196 \\
.1146\end{array}$ & $\begin{array}{l}.1208 \\
.1136\end{array}$ & $\begin{array}{l}.2422 \\
.2410\end{array}$ & $\begin{array}{l}.2436 \\
.2419\end{array}$ \\
\hline
\end{tabular}

t-ratios in parentheses.

*omitted as benchmark; 1980-1984 is benchmark unless otherwise noted.

Source: 2000 Census of Population, Public Use Microdata Sample, 5\% Sample. 
Appendix Table A-6

Regression Analysis of Earnings Among Adult Soviet Jewish Males

Who Immigrated Since 1965

Dependent Variable=LNEARN 2000 Census

\begin{tabular}{|c|c|c|c|c|c|c|c|c|}
\hline \multirow{2}{*}{$\begin{array}{c}\text { Immigration } \\
\text { Period: } \\
\text { Variable } \\
\end{array}$} & \multicolumn{2}{|c|}{$1965-2000$} & \multicolumn{2}{|c|}{$1965-1979$} & \multicolumn{2}{|c|}{$1980-1989$} & \multicolumn{2}{|c|}{$1990-2000$} \\
\hline & (1) & (2) & (1) & (2) & (1) & (2) & (1) & (2) \\
\hline CONSTANT & $\begin{array}{r}5.024 \\
(40.48)\end{array}$ & $\begin{array}{r}5.010 \\
(39.92)\end{array}$ & $\begin{array}{r}4.229 \\
(10.11)\end{array}$ & $\begin{array}{l}4.176 \\
(9.91)\end{array}$ & $\begin{array}{r}4.798 \\
(14.20)\end{array}$ & $\begin{array}{r}4.833 \\
(14.10)\end{array}$ & $\begin{array}{r}5.029 \\
(38.91)\end{array}$ & $\begin{array}{r}5.016 \\
(38.32)\end{array}$ \\
\hline EDUCYRS & $\begin{array}{r}.0732 \\
(19.17)\end{array}$ & $\begin{array}{r}.0736 \\
(19.00)\end{array}$ & $\begin{array}{l}.0791 \\
(6.36)\end{array}$ & $\begin{array}{l}.0789 \\
(6.34)\end{array}$ & $\begin{array}{l}.0885 \\
(9.74)\end{array}$ & $\begin{array}{l}.0880 \\
(9.52)\end{array}$ & $\begin{array}{r}.0683 \\
(15.32)\end{array}$ & $\begin{array}{r}.0689 \\
(15.26)\end{array}$ \\
\hline EXP & $\begin{array}{l}.0082 \\
(2.02)\end{array}$ & $\begin{array}{l}.0081 \\
(2.00)\end{array}$ & $\begin{array}{l}.0246 \\
(1.85)\end{array}$ & $\begin{array}{l}.0236 \\
(1.78)\end{array}$ & $\begin{array}{l}.0107 \\
(1.08)\end{array}$ & $\begin{array}{l}.0111 \\
(1.11)\end{array}$ & $\begin{array}{l}.0042 \\
(0.89)\end{array}$ & $\begin{array}{l}.0043 \\
(0.90)\end{array}$ \\
\hline EXPSQ & $\begin{array}{r}-.00022 \\
(-2.74)\end{array}$ & $\begin{array}{r}-.00023 \\
(-2.74)\end{array}$ & $\begin{array}{r}-.00062 \\
(-2.37)\end{array}$ & $\begin{array}{r}-.00061 \\
(-2.33)\end{array}$ & $\begin{array}{r}-.00024 \\
(-1.17)\end{array}$ & $\begin{array}{r}-.00024 \\
(-1.19)\end{array}$ & $\begin{array}{r}-.00014 \\
(-1.44)\end{array}$ & $\begin{array}{r}-.00014 \\
(-1.45)\end{array}$ \\
\hline LNWW & $\begin{array}{r}1.045 \\
(42.21)\end{array}$ & $\begin{array}{r}1.044 \\
(42.17)\end{array}$ & $\begin{array}{r}1.175 \\
(13.51)\end{array}$ & $\begin{array}{r}1.179 \\
(13.55)\end{array}$ & $\begin{array}{r}1.021 \\
(12.96)\end{array}$ & $\begin{array}{r}1.017 \\
(12.85)\end{array}$ & $\begin{array}{r}1.028 \\
(38.19)\end{array}$ & $\begin{array}{r}1.027 \\
(38.14)\end{array}$ \\
\hline IM95_00 & $\begin{array}{l}-.3272 \\
(-6.76)\end{array}$ & $\begin{array}{l}-.3215 \\
(-6.64)\end{array}$ & & & & & $\begin{array}{l}-.1233 \\
(-4.63)\end{array}$ & $\begin{array}{l}-.1257 \\
(-4.71)\end{array}$ \\
\hline IM90_94 & $\begin{array}{l}-.2093 \\
(-4.60)\end{array}$ & $\begin{array}{l}-.2024 \\
(-4.44)\end{array}$ & & & & & & \\
\hline IM85_89 & $\begin{array}{l}-.0228 \\
(-0.45)\end{array}$ & $\begin{array}{l}-.0175 \\
(-0.34)\end{array}$ & & & $\begin{array}{l}-.0147 \\
(-0.28)\end{array}$ & $\begin{array}{l}-.0102 \\
(-0.19)\end{array}$ & & \\
\hline IM75_79 & $\begin{array}{l}.0736 \\
(1.40)\end{array}$ & $\begin{array}{l}.0836 \\
(1.58)\end{array}$ & $\begin{array}{l}.0549 \\
(0.58)\end{array}$ & $\begin{array}{l}.0650 \\
(0.67)\end{array}$ & & & & \\
\hline IM70_74 & $\begin{array}{l}.0270 \\
(0.31)\end{array}$ & $\begin{array}{l}.0259 \\
(0.29)\end{array}$ & & & & & & \\
\hline IM65_69 & $\begin{array}{l}.0592 \\
(0.45)\end{array}$ & $\begin{array}{l}.0399 \\
(0.30)\end{array}$ & $\begin{array}{l}.0711 \\
(0.43)\end{array}$ & $\begin{array}{l}.0430 \\
(0.26)\end{array}$ & & & & \\
\hline ENGSPK & $\begin{array}{r}.3133 \\
(10.43)\end{array}$ & $\begin{array}{r}.3112 \\
(10.35)\end{array}$ & $\begin{array}{l}.3109 \\
(2.16)\end{array}$ & $\begin{array}{l}.3028 \\
(2.11)\end{array}$ & $\begin{array}{l}.2654 \\
(3.11)\end{array}$ & $\begin{array}{l}.2660 \\
(3.12)\end{array}$ & $\begin{array}{l}.3258 \\
(9.98)\end{array}$ & $\begin{array}{l}.3241 \\
(9.93)\end{array}$ \\
\hline MARRSP & $\begin{array}{l}.1413 \\
(5.68)\end{array}$ & $\begin{array}{l}.1441 \\
(5.78)\end{array}$ & $\begin{array}{l}.2947 \\
(3.69)\end{array}$ & $\begin{array}{l}.2962 \\
(3.69)\end{array}$ & $\begin{array}{l}.2275 \\
(3.86)\end{array}$ & $\begin{array}{l}.2304 \\
(3.89)\end{array}$ & $\begin{array}{l}.0879 \\
(3.03)\end{array}$ & $\begin{array}{l}.0903 \\
(3.11)\end{array}$ \\
\hline RURAL & $\begin{array}{l}-.1490 \\
(-0.95)\end{array}$ & $\begin{array}{l}-.1531 \\
(-0.97)\end{array}$ & $\begin{array}{l}.3456 \\
(0.52)\end{array}$ & $\begin{array}{l}.3252 \\
(0.49)\end{array}$ & $\begin{array}{l}.1459 \\
(0.39)\end{array}$ & $\begin{array}{l}.1520 \\
(0.40)\end{array}$ & $\begin{array}{r}.2357 \\
(-1.34)\end{array}$ & $\begin{array}{l}-.2430 \\
(-1.38)\end{array}$ \\
\hline SOUTH & $\begin{array}{l}-.0358 \\
(-1.11)\end{array}$ & $\begin{array}{l}-.0364 \\
(-1.13)\end{array}$ & $\begin{array}{l}-.0263 \\
(-0.26)\end{array}$ & $\begin{array}{l}-.0173 \\
(-0.17)\end{array}$ & $\begin{array}{l}-.0229 \\
(-0.27)\end{array}$ & $\begin{array}{l}-.0212 \\
(-0.25)\end{array}$ & $\begin{array}{r}.0403 \\
(-1.11)\end{array}$ & $\begin{array}{l}-.0422 \\
(-1.16)\end{array}$ \\
\hline UKRAINE & & $\begin{array}{l}-.0206 \\
(-0.73)\end{array}$ & & $\begin{array}{r}.0795 \\
(0.94\end{array}$ & & $\begin{array}{l}-.0933 \\
(-1.33)\end{array}$ & & $\begin{array}{l}-.0224 \\
(-0.67)\end{array}$ \\
\hline RELIG & & $\begin{array}{l}.0451 \\
(1.33)\end{array}$ & & $\begin{array}{l}.2817 \\
(2.53)\end{array}$ & & $\begin{array}{l}-.0199 \\
(-0.28)\end{array}$ & & $\begin{array}{r}-.0196 \\
(0.48)\end{array}$ \\
\hline OTHANCS & & $\begin{array}{l}.0547 \\
(1.88)\end{array}$ & & .1122 & & $\begin{array}{l}-.0174 \\
(-0.26)\end{array}$ & & $\begin{array}{l}.0677 \\
(1.96)\end{array}$ \\
\hline SAMPLE SIZE & 6492 & 6492 & 856 & 856 & 1240 & 1240 & 4394 & 4394 \\
\hline $\begin{array}{r}\text { STANDARD } \\
\text { ERROR }\end{array}$ & .8294 & .8292 & .9326 & .9305 & .8392 & .8396 & .8038 & .8036 \\
\hline R2 & .3436 & .3442 & .2736 & .2796 & .2319 & .2330 & .3622 & .3630 \\
\hline ADJUSTED R2 & .3422 & .3425 & .2650 & .2685 & .2262 & .2255 & .3609 & .3612 \\
\hline
\end{tabular}

t-ratios in parentheses.

Includes only immigrants who worked and had non-zero earnings in 1999.

Source: 2000 Census of Population, Public Use Microdata Sample, 5\% Sample. 